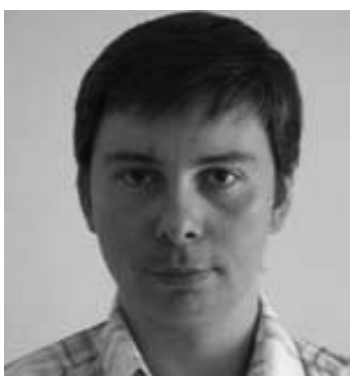

Adam Mazurkiewicz

Adam Mazurkiewicz - doktor, adiunkt w Zakładzie Dydaktyki Języka Polskiego i Literatury Uniwersytetu Łódzkiego. Zajmuje się literaturą i kulturą popularną oraz historią i teoria fantastyki. Autor monografii O polskiej literaturze fantastycznonaukowej lat 1990-2004 (2007) oraz artykułów ogłaszanych na łamach „Pamiętnika Literackiego", „Literatury i Kultury Popularnej”, uczelnianych zeszytów naukowych i w tomach pokonferencyjnych. 


\section{Nowelistyka Stefana Grabińskiego wobec tradycji literatury grozy}

tefan Grabiński postrzegany jest jako „twórca osobny”. Istotnie, nie stworzył żadnej szkoły, a poetyka jego beletrystyki, zwłaszcza nowel, nie cieszyła się większą popularnością, wyłączywszy naśladowców usiłujących dyskontować krótkotrwały sukces autora Demona $r u c h u^{2}$. Sam Grabiński w wypowiedziach teoretycznych podkreślał konieczność oryginalności, utożsamiając z nią „prawdziwą sztukę”. Oryginalność dzieła literackiego traktował jako artystyczną transpozycję postawy wobec zjawisk życiowych, wyrażającą się w szczególnym sposobie ich ujmowania ${ }^{3}$.

Oryginalność - zwłaszcza w potocznym rozumieniu tego pojęcia - jako wyznacznik wartości utworu zdaje się wykluczać odniesienia do tradycji. Jest to jednakże wykluczenie pozorne. Nawet jeśli bowiem na wzór dokonanego przez Grabińskiego w jednym ze szkiców krytycznoliterackich rozróżnienia przyjmiemy, że może ona kształtować się w różny

\footnotetext{
1 Opinie o wyjątkowości i walorach beletrystyki Grabińskiego pojawiały się już za życia autora. W przedmowie do II wydania Demona ruchu czytamy: „Twórczość Stefana Grabińskiego na gruncie polskiej beletrystyki przedstawia się zgoła niezwykle. Twórczość ta przedstawiałaby się niewątpliwie oryginalnie, a co najmniej swoiście i wyróżniająco, także na gruncie bogatszych piśmiennictw Zachodu, gdzie dorobek pisarski autora «Demona ruchu» $\mathbf{i}$ «Ciemnych sił» musiałby, $z$ natury rzeczy, utracić wiele ze swego nimbu nowości i twórczego odosobnienia - gdzie miałby swych poprzedników i tradycję rozwojową w przeszłości, a niejednego druha i ideowego współpropagatora w teraźniejszości" (J. Jedlicz, Stefan Grabiński, [w:] S. Grabiński, Demon ruchu, Lwów 1922, s. III). Sąd Józefa Jedlicza znajduje potwierdzenie w ocenie dorobku Grabińskiego, zamieszczonej na kartach Literatury polskiej XX wieku. Przewodnika encyklopedycznego (red. A. Hutnikiewicz, A. Lam, Warszawa 2000), gdzie czytamy: „Jest jedynym w naszej literaturze klasykiem noweli niesamowitej” (ibidem, t. 1, s. 204, hasło: Grabiński Stefan).

2 Artur Hutnikiewicz przytacza list Grabińskiego do Jerzego E. Płomieńskiego, w którym pisarz wylicza świadectwa recepcji własnej prozy w beletrystyce naśladowców, tytułując to zestawienie w znamienny sposób: Moja szkoła (naśladowcy, uczniowie i plagiatorzy) (TLSG, s. 91-92). Współcześnie również pojawiają się próby sięgania po poetykę charakterystyczną dla nowelistyki Grabińskiego. Czynią to przede wszystkim twórcy młodego pokolenia. Przykładem służą Konajace peryferie Arkadiusza Trzetrzelewskiego (City 1. Antologia polskich opowiadań grozy, red. B. Paszylek, Szczecin 2009) czy Banshee Wiktora Eryka Fossegrima (pochodzące ze zbioru idem, Gdy rozum śpi. Opowieści niesamowite, Przemyśl 2010).

3 "Twórczość literacka [jest] wszak wykwitem spotęgowanego niebywale życia - a życie, ów ciągły ruch i przemiana, owa nieustanna ewolucja w kierunku nam nieznanym jest zjawiskiem na wskroś oryginalnym. Życie i przyroda domagają się od artysty twórcy oryginalności. Brak jej wywołuje uczucie nudy, budzi szyderstwo" (S. Grabiński, Zagadnienie oryginalności w twórczości literackiej, „Pamiętnik Literacki” 1925/1926, s. 1).
} 


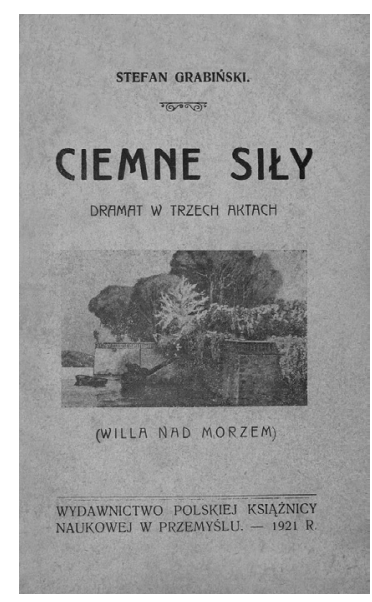

S. Grabiński, Ciemne sity (Willa nad morzem). Dramat w trzech aktach, Wydawnictwo Polskiej Książnicy Naukowej, Przemyśl 1921 sposób (od pełnej oryginalności pomysłu i jego realizacji, poprzez nowatorskie ujęcia tematów, po niespotykane dotychczas reinterpretacje tradycji kulturowej i literackiej ${ }^{4}$ ), pisarz musi opowiedzieć się wobec przeszłości. Dopiero sposób, w jaki to uczyni, przesądza o jego miejscu na literackim parnasie.

Podjęcie dialogu z tradycją może dokonać się oczywiście nie tylko poprzez przywołanie rozwiązań artystycznych, wskazujących na inspirację określonymi zjawiskami; o aktualizacji tradycji mówimy również wtedy, gdy stanowi ona negatywny punkt odniesienia. Jak zauważają autorzy Stownika terminów literackich, żywotność tradycji literackiej polega nie tylko na pozytywnym jej wykorzystywaniu, lecz również na mobilizacji sprzeciwu negujących ją twórców ${ }^{5}$. W obu wypadkach (tj. zarówno, kiedy autor kontynuuje historycznie identyfikowalną poetykę, jak i gdy ją odrzuca) przeszłość stanowi żywy dorobek kultury. Bohdan Suchodolski tę właściwość tradycji, dzięki której nie jest ona jedynie „świadectwem przeszłości”, ujmuje następująco:

W każdej chwili teraźniejszej trwa pewna przeszłość. [... ] W charakterze, w wyobraźni, w stylu myślenia i działania, w nastrojach i upodobaniach ujawnia się wielokrotnie ta nieświadoma, niewyrozumowna siła przeszłości żyjącej w czasie teraźniejszym. Stanowi ona istotną cząstkę składową naszego istnienia, jest rzeczywistością poświadczoną czynnie i odpowiedzialnie ${ }^{6}$.

Przywołany tu warunek, jaki Suchodolski stawia przed tradycją (tj. świadomość jej podjęcia), odróżnia refleksyjne zakorzenienie artysty w tradycji od tego, co można za Kazimierzem Wyką określić mianem „podobieństwa strukturalnego”. Intencjonalne (choćby polemiczne) nawiązanie do przeszłości literackiej należy odróżnić również od przypadkowej koincydencji, wynikającej z podjęcia analogicznej tematyki, bądź „ducha epoki” wpływającego na sposób jej ujęcia. Michał Głowiński definiuje tradycję literacką jako te elementy literackiej przeszłości, które zdolne są wpływać aktywnie na współczesną praktykę pisarską, stając się składową nowego układu historycznoliterackiego, a jednocześnie nie tracą znamion swej właściwej przynależności. Istota tradycji w jego rozumieniu nie polega na odwzorowywaniu formalnych cech zjawiska z przeszłości, lecz przetworzeniu go tak, aby oddawać duchowość czasów, w których zostaje przywołane ${ }^{8}$.

W najmniej dostrzegalny sposób związek dzieła z tradycją zachodzi w wypadku utworów w pełni nowatorskich, które Grabiński określał mianem „protuberancji twórczych sza-

4 Ibidem, s. 2-5. Prócz wymienionych tu trzech sytuacji twórczych Grabiński dostrzegał jedynie miałkość artystyczną utworów, których autorzy niezdolni byli do niczego, prócz jałowego naśladownictwa chwilowych mód literackich: „Jeżeli się nie ma nic światu do powiedzenia prócz [...] frazesów może pięknie brzmiących, może błyskotliwych i dowcipnych, lecz głucho dudniących wewnętrzną pustką, lepiej złamać pióro i milczeć" (ibidem, s. 5).

${ }^{5}$ Słownik terminów literackich, red. J. Sławiński, Wrocław 1998, s. 585, hasło: Tradycja literacka.

${ }^{6}$ B. Suchodolski, Zagadnienia żywej tradycji, "Glossy Poświęcone Kulturze i Piśmiennictwu” 1939, z. 1/2, s. $42-43$.

7 K. Wyka, Modernizm polski, Kraków 1968, s. 249-250.

8 M. Głowiński, Tradycja literacka. Próba zarysowania problematyki, [w:] Problemy teorii literatury. Seria I, red. H. Markiewicz, Wrocław 1987, s. 342. Zob. uwagę Jurija Tynianowa na temat odmiennej lektury twórczości Puszkina zależnie od świadomości literackiej jego czytelników: „Puszkin historyczny różni się od Puszkina symbolistów, lecz i tego nie utożsamimy z rewolucyjnym znaczeniem Puszkina w literaturze rosyjskiej; epoka zawsze dobiera potrzebne jej materiały, ale sposób wykorzystania tych materiałów charakteryzuje tylko ją samą" (idem, Fakt literacki, tłum. M. Płachecki, [w:] idem, Fakt literacki, tłum. E. Feliksiak, E. Korpała-Kirszak, J. Lenarczyk i in., wyb. E. Korpała-Kirszak, Warszawa 1978, s. 23). 
lonych fantastów" . Jednakże i w tym wypadku pisarz zobowiązany jest opowiedzieć się wobec tradycji. Już sam wybór konwencji nacechowany jest aksjologicznie. Jak zauważa Janina Abramowska, wybór elementów z przeszłości może służyć instrumentalnie, jako „podparcie” dla własnych racji, albo też - co istotniejsze - świadectwo poszukiwania języka zdolnego do wyrażenia stosunku artysty do świata. Wybór przywoływanej tradycji staje się wówczas dokumentem preferencji estetycznych i ideologicznych ${ }^{10}$.

Grabiński - debiutujący u kresu Młodej Polski, lecz inspirowany estetyką tej epoki i pozostający pod jej przemożnym wpływem - na wzór modernistów i symbolistów utożsamiał sztukę z medium między odbiorcą a rzeczywistością ${ }^{11}$. Jako teoretyk utożsamiał twórczość literacką z wykwitem spotęgowanego życia, którego istotę może oddać jedynie utwór prekursorski:

Im tęższa treść, im oryginalniejszy temat - tym trwalsze wrażenie. [...] Świadomość tego, iż się przynosi ze sobą światu myśl nową, pomysł znikąd rodem i dziewiczo świeży - dodaje twórcy rozmachu i uskrzydla mu mowę. Oryginalny pomysł, pod warunkiem jednak, że oryginalność jego nie będzie czysto zewnętrzną i płytką sensacją, lecz w dziwną fabułę przybraną głęboką treścią - znajdzie najszczęśliwszą dla siebie formę objawu: język, styl i literacką ekspresję ${ }^{12}$.

Jednakże kwestia tradycji literackiej (czy szerzej - kulturowej) to nie tylko problem wykorzystywanych konwencji. To również stosunek autora do przeszłości postrzeganej przez pryzmat pamięci ${ }^{13}$. Toteż pod pozorami przywołań kulturowych dawnych czasów może skrywać się współczesność autora. Dlatego też uobecnianie przeszłości może być np. grą z przeszłością, jak ma to miejsce w nowelistyce Grabińskiego zazwyczaj w odniesieniu do utworów zawierających w tytule wyróżniki gatunkowe; przykładem służą: Głucha przestrzeń. (Ballada kolejowa), Wieczny pasażer. (Humoreska), Btędny pociag. (Legenda kolejarska) z tomu Demon ruchu; Biały wyrak. (Gawęda kominiarska), Pirotechnik. (Baśń astralna)

9 S. Grabiński, Zagadnienie oryginalności w twórczości literackiej, s. 3.

$10 \mathrm{~J}$. Abramowska, Dawność we współczesności, [w:] eadem, Rekonstrukcje i konstrukcje. Studia literackie, Poznań 2003, s. 105-106. Przywoływane przez Abramowską motywacje, przyświecające pisarzowi ustosunkowującemu się wobec tradycji, nie wyczerpują tej problematyki. Pośród innych możliwych powodów aktualizacji "dawności" w literaturze współczesnej pisarzowi, równie istotnych dla autorskich wizji przeszłości, Abramowska wymienia aktualizacje zbiorowej podświadomości ("ducha epoki”) oraz przejawy świadomości fałszywej.

11 Tadeusz Krajewski poszukuje dla twórczości Grabińskiego innych niż modernistyczne punktów odniesienia. Jego zdaniem fundamentalne dla pisarza pozostają: platońska relacja między myślą i materią; przekonanie o wielości rzeczywistości oraz inspirowana refleksją Heraklita z Efezu koncepcja wiecznego przeistaczania się bytu (idem, "Książę fantastów”. Stefan Grabiński - polski Lovecraft, "SFera” 2003, nr 1). Z uwagi na skrótowy charakter szkicu Krajewski nie rozwija sygnalizowanych przez siebie tez. Wydaje się jednak, że poszukiwania filozoficznego uzasadnienia koncepcji bytu i natury świata prezentowanych przez Grabińskiego w myśli antycznej jest bezzasadne. Najbliższą Grabińskiemu filozoficznie tradycją jest bowiem Bergsonowski intuicjonizm i koncepcja élan vital (na temat wpływu filozofii Bergsona na twórczość Grabińskiego zob.: B. Kopon, Грабинский Стефан (26 февраля 1887-12 ноября 1936), „Архив Фантастики”, http://www.archivsf.narod.ru/ [dostęp: 21.03.2013]; P. Kobus, Somnambulicznym pociagiem na drugi brzeg, „Fahrenheit. Science-fiction, Fantasy \& Horror" 2007, nr 58, s. 17, http://www.fahrenheit.net.pl/archiwum/f58/17.html [dostęp: 21.03.2013]). Nie bez znaczenia pozostaje też fascynacja Grabińskiego koncepcjami Williama Jamesa, zwłaszcza dotyczącymi jaźni.

12 S. Grabiński, Zagadnienie oryginalności w twórczości literackiej, s. 2.

13 "Obraz przeszłości dostępnej w naszym o niej wyobrażeniu i jego intensywność to zawsze mniej aniżeli przeczucie naszej o niej pamięci, cząstkowej i spowitej kirem zapomnienia. Nasza pamięć z kolei, poddana władzy, jaką sprawuje nad nią nasza teraźniejszość, jest zawsze uboższa od przeszłości, danej intuicyjnie w nieprzekładalnych na obraz pomyśleniach o niej. To pewność dnia dzisiejszego sprawia, że wczoraj jest tak nieuchwytne" (M. Zaleski, Formy pamięci, Gdańsk 2004, s. 12). 


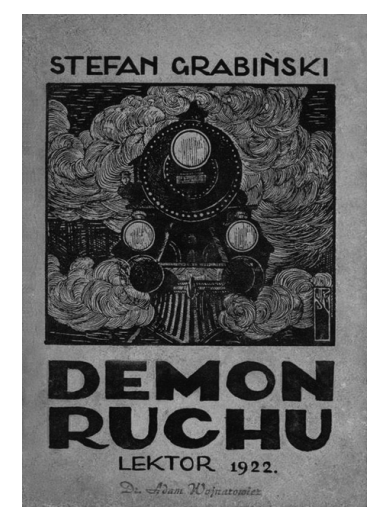

S. Grabiński, Demon

ruchu, Instytut Literacki

„Lektor"Sp. z 0.0., Lwów

[i in.] 1922 (wyd. II)

z Księgi ognia. Określenia te nie mają charakteru sugestii genologicznych; to raczej - zwłaszcza w odniesieniu do terminów „ballada” i „gawęda” - pragnienie przywołania stereotypowych wyobrażeń na temat romantyzmu jako epoki obnażającej dwoistość bytu. Szczególnie ballada, jako gatunek obarczony tradycją romantyczną, umożliwia wprowadzanie w obręb świata przedstawionego elementów nadprzyrodzony $\mathrm{ch}^{14}$. Jednakże $\mathrm{w}$ analogicznej, co określenia utrwalone tradycją teoretycznoliteracką, funkcji Grabiński wykorzystuje formy imitujące literaturę faktu (pamiętnik, notatki).

Artur Hutnikiewicz akcentuje rangę „uwag”, które - z perspektywy innej niż zaprezentowana w ramach „właściwej” opowieści - dopowiadają losy protagonisty. Taki - wykraczający poza czas „akcji właściwej” - epilog (imitujący niekiedy edytorski dopisek) odgrywa istotną konstrukcyjną i kompozycyjną rolę: jest najczęściej potwierdzeniem domysłów czytającego, sugerowanych mu przez tok fabularnych zdarzeń. Najczęściej jednakże rozwiązanie perypetii stoi w sprzeczności z pozaliterackim doświadczeniem odbiorcy, toteż opowieść nie tylko nie traci na niesamowitości, lecz przeciwnie - groza zostaje spotęgowana poprzez sugestię, iż czytelnik ma do czynienia z „autentykiem”. Dzieje się tak, ponieważ wprowadzony peritekst (określenie Gérarda Genettea ${ }^{15}$ ) umożliwia stworzenie iluzji „obiektywizmu” ich „autora” poprzez wyodrębnienie typograficzne (przykładem są - wydzielone podtytułem Dopisek wydawcy pamiętnika - notatki dołączone do zasadniczej części Przed droga daleka (1922) oraz - opatrzona tytułem Epilog wydawcy pamiętnika - notka w Projekcjach [1930]). Dzięki peritekstom wprowadzony zostaje dystans odgrywający istotną rolę: pozwala bowiem na wyjaśnienie zagadki, której rozwiązanie fabuła noweli jedynie sugerowała ${ }^{16}$. Rozpatrywane jako rodzaj zabawy, periteksty są ważne w szczególnej grze autora z czytelnikiem, w której obnażony zostaje literacki charakter ich statusu wobec „tekstu głównego”, a ich odrębność okazuje się pozorna. W perspektywie komunikacji literackiej periteksty można traktować jako wyraz refleksji nad ich autorstwem oraz angażując go w poszukiwanie „prawdziwego” ich twórcy, a tym samym dostrzeżenie literackiej mistyfikacji ${ }^{17}$.

14 Grabiński na temat własnych związków z tradycją romantyczną (traktując ją jako negatywny punkt odniesienia) pisał następująco: „W przeciwstawieniu do fantastyki romantycznej, która traktowała żywioł swój jako ornamentykę i środek symboliczny, fantastyka moja ma charakter autonomiczny i była dla mnie [...] wyrazem światopoglądu" (Sylwetki pisarzy Iwowskich. Stefan Grabiński [autoreferat], "Lwowskie Wiadomości Muzyczne i Literackie" 1934, nr 83, s. 1). Częściowo opinię Grabińskiego podziela Artur Hutnikiewicz, widzący w fantastyce epoki romantyzmu jedynie elementy dekoracyjne: „Istotą tej fantastyki, czerpiącej pomysły głównie ze skarbca wierzeń ludowych, jest jej świadomie założona umowność, fikcyjność, konwencjonalizm, dekoracyjność. Ten świat Goplan, Świtezianek, Chochlików, Skierek, elfów, gnomów i demonów najrozmaitszego rodzaju jest tylko i wyłącznie wykładnikiem pewnej metody literackiej, igraszką rozbawionej wyobraźni, mieniącą się barwami tęczy baśnią, którą rozkoszuje się poeta romantyczny" (idem, Jeszcze w sprawie fantastyki, "Tygodnik Powszechny” 1950, nr 38, s. 4). Jakkolwiek jednak dość często (zwłaszcza w XVIII-wiecznej powieści gotyckiej) zdarzenia fantastyczne zyskiwały racjonalne wyjaśnienie, twórcy romantyczni odeszli od tej gry z czytelnikiem na rzecz odsłaniania „mrocznej strony bytu”. Czynili to za pomocą przełamywania jedności ontologicznej świata przedstawionego poprzez wprowadzanie w jego obręb zjawisk wywodzących się z odmiennego porządku rzeczywistości. Tendencję do irracjonalizacji wykładni sensów można zauważyć zwłaszcza w nurcie „czarnego romantyzmu”, który usankcjonował estetyzację wielu figur pierwotnie inspirowanych folklorem, obecnie zaś charakterystycznych dla fantastyki grozy (np. wampira, sobowtóra, wilkołaka). Podobnie do przywołanych istot z fantastycznego bestiariusza są reinterpretowane byty, dla których punktem odniesienia są ludowe wierzenia: przykładem demony z Zemsty żywiołaków (1922) i Białego wyraka (1922).

15 G. Genette, Paratext. Thresholds of Interpretation, tłum. J. E. Lewin, Cambridge 1997. Genette koncentruje się na edytorskim wymiarze peritekstów, jednakże porusza również kwestię gry autora z czytelnikiem w rozpoznanie kreacji fikcyjnego ich twórcy (ibidem, s. 37).

16 TLSG, s. 422.

17 S. Studniarz, Rola peritekstów w „Opowieści Artura Gordona Pyma”, [w:] Edgar Allan Poe. Klasyk grozy i perwersji - i nie tylko..., red. E. Kasperski, Ż. Nalewajk, Warszawa 2009, s. 153-154. 
W tradycji literackiej, którą można przywołać jako punkt odniesienia dla nowelistyki Grabińskiego, istotne miejsce zajmuje nurt niemieckojęzycznych wczesnoromantycznych opowieści o duchach (Geistergeschichte; obocznie pojawia się też termin Gespenstergeschichte). Gerard Koziełek, publikując wybór reprezentatywnych dla tego nurtu opowieści, zauważył charakterystyczną prawidłowość: polegała ona na zanegowaniu wprowadzonych uprzednio niesamowitych zjawisk poprzez ich racjonalną wykładnię. Atmosfera grozy, ewokowana przez obecność rzekomych „widm”, zostaje w Geistergeschichte sfunkcjonalizowana dla wywołania nastroju grozy, a następnie ujęta w cudzysłów, wyrażający się autorskim dystansem do opisywanych zdarzeń, poprzez ich - zgodną z logiką świata pozatekstowego interpretację $\mathrm{w}$ duchu racjonalizmu ${ }^{18}$. Choć jednak preromantyczne opowieści o duchach demaskują zjawiska uznane przez protagonistów za nadprzyrodzone, pojawia się również migotliwość interpretacyjna obserwowanych zdarzeń. Ma to miejsce zwłaszcza w wariancie psychologicznym Geistergeschichte, w którym ukazane zostają fenomeny niemożliwe do jednoznacznej interpretacji, mimo że w ramach świata przedstawionego nie manifestują się byty ontologicznie obce (duchy, upiory, demony) ${ }^{19}$.

Znamienne dla „opowieści o duchach” przenikanie dwu sfer rzeczywistości - racjonalnej i nadprzyrodzonej - Grabiński wykorzystuje do ukazania dwoistej natury świata. Przy czym, co ciekawe, służą mu do tego nie tylko istoty nadprzyrodzone, charakterystyczne dla nurtu preromantycznego, lecz - przede wszystkim - fenomeny psychologiczne, rozważane przezeń jako przejawy życia psychicznego. Szczególną rolę w twórczości tej odgrywa figura sobowtóra. Być może w tendencji do rozpatrywania sobowtóra w kategoriach psychoanalitycznych należy upatrywać wpływu na twórczość Grabińskiego rozprawy Otto Ranka Der Doppelgänger. Psychoanalytische Studio (1914). Wielość wariantów aktualizacji tej figury i liczne powroty do motywu Doppelgängera pozwalają na potraktowanie go jako szczególnie znaczącego w literackiej twórczości Grabińskiego (Brian Stableford nie waha się określić fascynacji pisarza figurą sobowtóra mianem obsesyjnej ${ }^{20}$ ). Zgodnie $\mathrm{z}$ utrwaloną w tradycji kulturowej wykładnią, sobowtór w beletrystyce Grabińskiego pozostaje alter ego protagonisty, zarazem stanowiąc mroczną stronę jego osobowości ${ }^{21}$. Jan Wyka, referując twórczość Grabińskiego, zauważy1, że sobowtór jest w niej wyrazem „istnienia osobnego”, którego nie sposób zracjonalizować:

Rozdwojenie [bohatera - A. M.] stanowilo o wewnętrznym splątaniu, skazując [...] na wzajemność, na istnienie oboczne. Stworzony przez fatum sobowtór mógł być równie dobrze mordercą, albo trucicielem, czy też czarodziejem władającym biegiem dni i lat bohatera. [ ... ] Mocodawcami były sily nadprzyrodzone, autonomiczne, niezależne od człowieka ${ }^{22}$.

${ }_{18}$ G. Koziełek, Wstęp, [do:] Czarny pająk. Opowieści niesamowite z prozy niemieckiej, wyb. G. Koziełek, Warszawa 1976, s. 11.

19 R. A. Zondergeld, Lexikon der phantastischen Literatur, Frankfurt 1983, s. 278, hasło: Gespenstergeschichte.

20 B. Stableford, News of the Black Feast and Other Random Reviews, [b.m.w.] 2009, s. 79.

${ }_{21}$ Związek postaci sobowtóra z problematyką tożsamości indywidualnej jaźni legł u podstaw wykładni romantyzmu Davida Morse'a (Romanticism. A Structural Analysis, London 1982, s. 76). Zauważa on, że problem tożsamości protagonisty twórcy romantyczni rozwiązywali dzięki rozbiciu osobowości jednostki na liczne postacie, których status ontologiczny jest niejednoznaczny, a sama tożsamość wymyka się licznym formom, za pomocą których jest manifestowana. Kwestia tożsamości ewokuje zarazem - jak zauważają Andrzej Pankalla i Zenon W. Dudek (Psychologia kultury. Doświadczenia graniczne i trans kulturowe, Warszawa 2005, s. 103) - problematykę związaną z samookreśleniem dokonanym na drodze identyfikacji podmiotu z tym, co łączy, a nie dzieli: „Refleksja nad granicą i związanym z nią Innym to często wybór pomiędzy normalnością a odstępstwem od niej, naturalnością a wtórnością, wybór pomiędzy lepszym i gorszym".

22 J. Wyka, Literatura i upiory, "Twórczość" 1981, nr 5, s. 135.

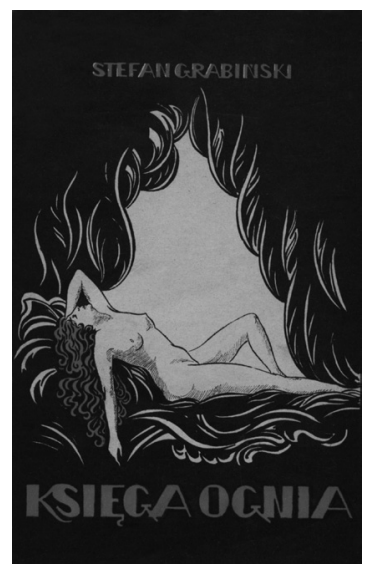

S. Grabiński, Księga ognia. Nowele, Księgarnia Polska, Łódź 1922

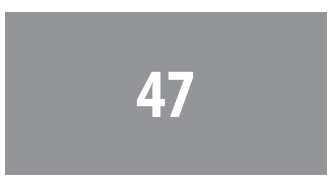


Wydzielenie z charakteru protagonisty negatywnych cech i obarczenie nimi sobowtóra pozwala niekiedy na rozdwojenie bohatera po to, by odpychane aspekty ego (konstytutywne dla sobowtóra) doprowadzily jednostkę do autodestrukcji. Interesującym punktem odniesienia dla utworów Grabińskiego, podejmujących problematykę unicestwienia sobowtóra, pozostaje - prócz nowelistyki Poego, a zwłaszcza Williama Wilsona (1839) oraz Portretu owalnego (1842) - modernistyczna powieść Oskara Wilde’a Portret Doriana Graya (1890). Trudno oczywiście traktować utwór Wilde’a jako inspirację dla nowel Grabińskiego; jest to raczej wyraz zbieżności zainteresowań obu pisarzy rozdwojeniem osobowości jako jedną z psychoz neurastenicznych ${ }^{23}$. Poszukiwanie źródeł grozy w osobowości protagonisty zbliża twórczość Grabińskiego do nowelistyki Edgara Allana Poego, którego opowieści niesamowite autor Demona ruchu cenił na tyle wysoko, że poświęcił mu jeden ze szkiców ${ }^{24}$. Niczym np. w Poeowskim Williamie Wilsonie, również w nowelistyce Grabińskiego pojawiają się postacie pożywiające się jestestwem protagonistów (szczególnym przypadkiem istoty łączącej w sobie cechy takiego wampira i sobowtóra jest Sara Braga z $W$ domu Sary; między nią i jej kochankami zachodzi szczególne podobieństwo: ofiary kobiety demona stają się jej częścią, ona zaś egzystuje w nich ${ }^{25}$ ). Przykładem służą m.in. nowele: Zez (1918), Saturnin Sektor (1920) oraz Problemat Czelawy (1920). Zarówno Zez, jak i Problemat Czelawy można rozpatrywać również jako reinterpretacje figury rozdwojenia osobowości, obecną np. w Dziwnej historii doktora Jekylla i Mr. Hyde'a Roberta Louisa Stevensona $(1886)^{26}$. Pogłos

${ }^{23}$ W tym względzie Wilde i Grabiński pozostają kontynuatorami fascynacji tym fenomenem Hoffmana (m.in. Magnetyzer, 1814; Sobowtór, 1821) oraz Marcela Schwoba (Le Livre de Monelle, 1894). Za podbudowę psychologiczną artystycznych opracowań motywu sobowtóra można w modernizmie uznać Les Maladies de la personnalité (1885) Theodule-Armanda Ribota oraz wspomnianą rozprawę Otto Ranka.

${ }^{24}$ S. Grabiński, Książę fantastów (E.A. Poe). Studium literackie, „Lwowskie Wiadomości Muzyczne i Literackie" 1931, nr 3, s. 1; nr 4, s. 1-2; nr 5, s. 2-3. Fascynacja opowieściami Poego i refleksy ich lektury w twórczości Grabińskiego nie ograniczają się do naśladowania stylistyki bądź rozwiązań fabularnych. Jest to temat na osobną pracę. Tu jedynie sygnalizujemy ten problem ze świadomością wpływu, jaki nowelistyka Poego wywarła na kształt modernistycznych "opowieści niesamowitych” (Leon Lemonnier nie waha się określić pisarza mianem un grand accoucheur generacji artystów przełomu XIX i XX w., zob. idem, Edgar Poe et les conteurs français, Paris 1947, s. 91; na temat modernizmu Poego zob. E. Kasperski, Edgar Allan Poe. Tożsamość $i$ konteksty. Wprowadzenie do lektury, "Tekstualia” 2009, nr 1, s. 15-34; idem, Czy Poe był modernistq?, [w:] Edgar Allan Poe, s. 305-335).

Innym pisarzem, który mógł wywrzeć wpływ na twórczość literacką Grabińskiego, był Howard Philips Lovecraft. Biorąc jednak pod uwagę, że Grabiński w latach 30. zaczął wycofywać się z aktywnego życia artystycznego, nie można mówić o inspiracji opowieściami Lovecrafta, tym bardziej iż rodzimemu czytelnikowi udostępnione były dopiero w latach 60. XX wieku (S. T. Joshi, H. P. Lovecraft. Biografia, tłum. M. Kopacz, Poznań 2010, s. 1086). Obu artystów łączy wspólnota wyobraźni, pozwalająca odnaleźć pokrewne tematy i sposoby ujęcia, oraz fascynacja twórczością Poego. W wypadku pierwszego wyraziła się ona w postaci osobnego eseju Nadnaturalny horror w literaturze (1925-1927), w którym Lovecraft o Poem pisał: „W latach trzydziestych XIX w. miał miejsce literacki renesans nie tylko w historii opowieści grozy, ale w ogóle w całej literaturze, mający wpływ na trendy wielkiej europejskiej szkoły estetycznej. Mamy szczęście jako Amerykanie, że nastąpił u nas, w osobie naszego najsłynniejszego i najnieszczęśliwszego rodaka: Edgara Allana Poe" (idem, Nadnaturalny horror w literaturze, tłum. A. Ledwożyw, Ł. M. Pogoda, R. Lipski, Warszawa 2008, s. 46). Grabiński dał wyraz zauroczeniu pisarstwem Poego we wspomnianym szkicu Ksiq̨żę fantastów. Ponadto można do obu twórców odnieść słowa Marka Wydmucha, charakteryzujące pisarstwo Lovecrafta: „Spotykają się tu [...] romantyzm i racjonalizm, staroświecczyzna i nowoczesność, świat demonów i świat «science fiction» - sfery, zdawałoby się, nieprzywiedlne, a przecież często zaspokajające, każda na swój sposób, te same głody ludzkiej psychiki" (idem, Cień z Providence, [w:] H. P. Lovecraft, Zew Cthulhu, tłum. R. Grzybowska, Warszawa 1983, s. 15).

${ }^{25}$ B. Zwolińska, Wampiryzm w literaturze romantycznej i postromantycznej. Na przykładzie "Opowieści niesamowitych" Edgara Allana Poego, "Poganki" Narcyzy Żmichowskiej oraz opowiadań Stefana Grabińskiego, Gdańsk 2002, s. 140.

${ }^{26}$ Grabiński w Zagadnieniu oryginalności w twórczości literackiej odżegnuje się od powinowactw Problematu Czelawy z utworem Stevensona: „Noweli Stevensona nie znałem i znać nie mogłem [...] bo nic nie wiedziałem o jej istnieniu”. Wskazuje przy tym na rozbieżności między opracowaniem tematu w obu utworach: "Nowela Stevensona jest artystycznie ujętym problemem pewnej choroby psychicznej, gdy mój utwór zajmu- 


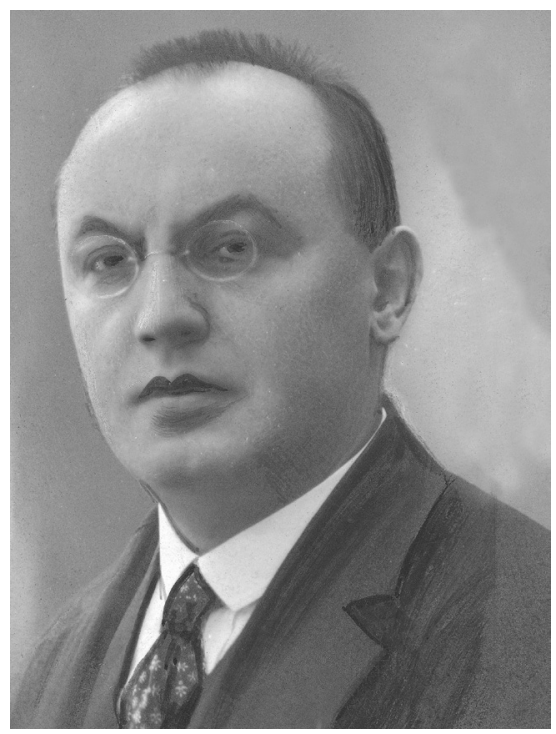

Józef Jedlicz (1878-1955),

przyjaciel Grabińskiego,

potencjalny kontrkandydat,

a ostatecznie członek

z ramienia magistratu jury,

które przyznało pisarzowi

w 1931 r. nagrodę literacką

miasta Lwowa.

Ze zbiorów Narodowego

Archiwum Cyfrowego

utworu Stevensona zdaje się pobrzmiewać również w Czadzie (1919); starzec-Makryna to astralna istota androgyniczna, uosabiająca różne aspekty psyche, toteż kiedy protagonista zabija wiedźmę, ginie również mężczyzna: „Na podłodze, na nędznym tapczanie leżały dwa nagie trupy: olbrzymiego starca i Makryny - zbroczone obficie posoką. Oboje mieli tę samą śmiertelną ranę, koło lewej pachy, nad sercem...”27.

W twórczości przywoływanych tu artystów jest ponadto zauważalne dążenie do takiego kreowania nastroju niesamowitości, u podstaw której leży odwołanie się do wyobraźni czytelnika, dopowiadającej to, co autor jedynie zasugerował. Można tu przytoczyć opinię Felicjana Faleńskiego, piszącego o nowelistyce Poego: „Zdaje ci się, jakbyś zajrzał w nieznane jakieś głębie, w których oko twoje na próżno dna szuka. Dopracowywasz [!] myślą więcej może, niż się to zamarzyło autorowi samemu"28. Słowa te zdają się oddawać istotę pisarstwa Grabińskiego. Na niedopowiedzeniu, sugestii oparte są zwłaszcza te nowele,

je się fenomenem pewnego kaprysu, wybryku psychofizycznego natury [...]. Dlatego [...] uważam Problemat Czelawy za utwór oryginalny a stąd potrzebny i zupełnie na miejscu" (ibidem, s. 3-4).

Oczywiście trudno zbieżności w opracowaniu motywu sobowtóra u Poego, Stevensona i Grabińskiego uznać za wyraz aluzji literackiej. Nowele Grabińskiego, w których pojawia się figura Doppelgängera, zazwyczaj nie spełniają podstawowych warunków stawianych aluzji przez Andrzeja Stoffa (Tezy o aluzji literackiej, [w:] Aluzja literacka. Teoria - interpretacja - konteksty, red. A. Stoff, A. Skubaczewska-Pniewska, Toruń 2007, s. 19-21). Jest to raczej efekt zbieżności w programach artystycznych pisarzy, w których główne miejsce przypada fascynacji mrocznymi stronami osobowości człowieka. Można jednak na przywołane tu utwory spojrzeć z innej strony. Załóżmy istnienie w nowelistyce Grabińskiego „powinowactw z wyboru” z twórczością Poego. Wchodziłyby one wówczas w obręb zjawiska, które Konrad Górski określa mianem aluzji pośredniej. Jest to szczególna postać aluzji literackiej, usytuowana na pograniczu świadomego nawiązania i przypadkowej zbieżności wynikającej z podejmowanej tematyki. Jednym z jej przejawów jest reminiscencja świadoma bez intencji aluzyjnych (K. Górski, Aluzja literacka (istota zjawiska i jego typologia), [w:] Problemy teorii literatury. Seria I, s. 332-334). Z pewnością można odnaleźć związek między nowelą Gebrowie Grabińskiego a Systemem doktora Smoły i profesora Pierza Poego; zależność łączy też Na tropie z Berenice. Krzysztof Bortnik i Krzysztof Maciej Choule upatrują związek Noclegu z Poeowskim Przedwczesnym pogrzebem, traktując nowelę Grabińskiego jako przetwarzającą à rebours motyw z opowieści Poego (zob. Od Redakcji, [w:] Maska śmierci. Opowieści niezwykłe, red. K. Bortnik, K. M. Choule, Przemyśl 2010, s. 10).

27 S. Grabiński, Czad, „Pro Arte” 1919, z. 2, s. 16.

${ }^{28}$ F. Faleński, Edgar Allan Poe i jego nowele, „Biblioteka Warszawska” 1861, t. 4, nr 1, s. 39. 
które wykorzystują figurę wampira (Kochanka Szamoty, $W$ domu Sary). Aby uniknąć mało wyrafinowanych artystycznie (choć czytelniczo efektownych) opisów - do których mogli być przyzwyczajeni amatorzy jarmarcznych opowieści o nosferatu - autor kreuje „gęstą” atmosferę, wykluczającą jednoznaczność interpretacji zaprezentowanych odbiorcy zjawisk ${ }^{29}$. Niczym w Poeowskiej Zagładzie domu Usherów, Grabiński w przywołanych tu utworach wciąż odsuwa nieuchronną katastrofę, potęgując tym samym mroczny nastrój ${ }^{30}$.

Jednym ze sposobów osiągnięcia efektu zagubienia czytelnika jest kreowanie przestrzeni świata przedstawionego tak, aby podkreślić jej niedookreślenie. Zabieg ten, służący Grabińskiemu do kreacji atmosfery niepewności, może być inspirowany analogicznym chwytem, którym posłużyła się Narcyza Żmichowska w Pogance (1846). W powieści nie sposób określić przemierzanych odległości do zamku Aspazji: „Pędziliśmy oboje, a tylko z ruchu i ze słuchu miarkowałem, że po kamieniach lub po piasku, że po zagonach lub po łąkach pluskających wilgocią" ${ }^{31}$. W obu wypadkach pojawia się dysonans poznawczy - odbiorca (wespół z protagonistą) traci orientację w czasie i przestrzeni. Zabieg ten pozwala na wyizolowanie opisywanej przestrzeni od wplywów zewnętrznych, a zamknięta enklawa potęguje nastrój klaustrofobii, towarzyszący czytelnikowi w trakcie lektury. Nawet jeśli - jak w noweli Grabińskiego $W$ domu Sary - topografia tytułowej siedziby zostaje dookreślona, jest to doprecyzowanie pozorne. Wprawdzie czytelnik potrafi ulokować miejsce w miarę precyzyjnie na planie miasta, jednakże nazwa miejscowości nie zostaje wymieniona: „«Polanka» leżała w dość znacznej odległości od środka miasta i dopiero po półgodzinnej jeździe stanęliśmy u celu”32.

Grabiński, odwolując się do tradycji fantastyki grozy, nie poprzestaje na powielaniu charakterystycznych dla niej wzorców fabularnych: wampir w jego nowelistyce nie jest istotą pożywiającą się krwią, lecz energią psychiczną ${ }^{33}$. Zarazem jednak ma wiele atrybutów przypisywanych mu na mocy tradycji ludowej i literackiej (umiejętność hipnozy, zdolność do przedłużania własnej egzystencji kosztem innych). Toteż czytelnicy Kochanki Szamoty mogli identyfikować tę istotę na podstawie własnych doświadczeń lekturowych i obrazu bohatera zwampiryzowanego, zakorzenionego w świadomości zbiorowej. Pamięć wspólnotowa to szczególnie istotny punkt odniesienia dla fantastyki grozy, której twórcy inspirują się autorytetem tradycji. Jako wytwór przeszłości, świadomość zbiorowa opiera się na tradycji, aby potwierdzić własną rolę w kształtowaniu życia społeczności. Dlatego pisarz przywołu-

29 Migotliwości znaczeń nabiera też w opowieściach tych figura wampira: to nie tylko przerażająca istota wiodąca niepojętą egzystencję kosztem swych ofiar, lecz również - jak w Wampirze - buntownik przeciw prawom natury, takim jak przemijanie (postać główna noweli nie posila się krwią, lecz własnym pragnieniem przedłużenia egzystencji, zob. Wampir, [w:] S. Żalny [S. Grabiński], Z wyjątków. W pomrokach wiary, Lwów 1909).

30 Zob. PD, s. 235.

31 N. Żmichowska, Poganka, [w:] eadem, Pisma Gabryelli, t. 2, Warszawa 1861, s. 99-100.

32 S. Grabiński, W domu Sary, [w:] idem, Niesamowita opowieść, Lwów 1922, s. 67.

33 Tendencja, by poddawać konwencjonalne postacie, charakterystyczne dla fantastyki grozy, zabiegom racjonalizacji wypływa nie tylko z artystycznego programu Grabińskiego. Jest ona znamienna dla twórczości modernistycznej, w której - jak zauważył Ignacy Matuszewski (Diabeł w poezji. Historia i psychologia postaci uosabiających zło w literaturze pięknej wszystkich narodów i wieków. Studium literacko-porównawcze, Warszawa 1899, s. 218) - złu odebrany zostaje wymiar jednostkowy. W zamian pojawiają się jego miazmaty, wypełniające atmosferę swymi emanacjami. Brak osobowego charakteru zła przyczynia się też do zamiany zobiektywizowanego demona w subiektywne objawy choroby psychicznej (schorzenia bohaterów przybierają najczęściej dwie opozycyjne formy: demonolatrii lub demonofobii). Podobnie definiował Szatana Stanisław Przybyszewski, według którego to „pojęcie wszystkiego [...], za co prawa boskie i ludzkie nakładają kary” (idem, Na drogach duszy, Kraków 1901, s. 89). Prócz tendencji do racjonalizacji fenomenów niewytłumaczalnych rozumowo można w nowelistyce Grabińskiego odnaleźć konwencjonalne opracowania wątków związanych z satanizmem; przykładem służy Opowieść o grabarzu. (Gawęda zaduszna), "Maski” 1918, z. 31, w której bluźnierczość kształtu nagrobków budzi gniew zmarłych, nawiedzających mieszkańców miasteczka. 
jący figury obecne w imaginarium interpersonalnym zmuszony jest opowiedzieć się wobec tradycyjnego sposobu ich przedstawiania ${ }^{34}$. Kontekst kulturowy w odniesieniu do beletrystyki Grabińskiego jest tym istotniejszy, że pisarz ten był - jak przypomina Karol Irzykowski - znawcą demonologii: „Oczytywał się [... ] w literaturze niesamowitej, spirytystycznej, demonologicznej i zaczął nawet wierzyć w cuda czarnej i białej magii, w ukazywanie się duchów itp."35 Toteż autorskie wizje należy uznać za podbudowane syntezą tradycji folklorystycznej i pseudonaukowej wiedzy, jakiej dostarczała czytelnikowi literatura jarmarczna (popularna na przełomie XIX i XX wieku oraz przez cały okres międzywojnia ${ }^{36}$ ), a także adresowanych do bardziej ambitnego odbiorcy publikacji Polskiego Towarzystwa Astrologicznego bądź specjalizującego się w ezoteryce wydawnictwa „Lotos” ${ }^{37}$.

W twórczości Grabińskiego szczególnie wyraziście relacje między tradycją kulturową a jej autorską aktualizacją można zaobserwować - prócz Kochanki Szamoty - na przykładzie opisów wyglądu ofiar wampirów, zamieszczonych m.in. na kartach noweli $W$ domu Sary; jeden $z$ bohaterów, poddany władzy wampirzycy, zdaje się ulegać śmiertelnej chorobie: „Twarz niegdyś zdrową, tryskającą młodym, bujnym życiem, oblekła chorobliwa bladość, oczy przesłoniła mgła zadumy, której bezwład i beztreściowość tworzyły bolesny kontrast ze szlachetną linią rysów" ${ }^{38}$.

$\mathrm{Z}$ wampiryzmem jako zagrożeniem dla protagonisty łączy się w nowelistyce Grabińskiego lęk przed kobietą i kobiecością. Postrzeganie kobiety jako źródła zła w relacjach społecznych i osobowych zakorzenione było w antropologii przełomu XIX i XX wieku. Richard von Krafft-Ebing w pracy z 1888 roku dowodził związku biologii kobiety z jej moralnością:

Bardzo często życie płciowe histeryczek jest chorobliwie podniecone. Skutkiem tego może być najwstrętniejsza prostytucja nawet u mężatek. [... ] Nader często chorobliwie wzmożony popęd płciowy „usposobione ku temu dziewczęta” zmienia w Messaliny. Pożądliwość często ujawnia się w kokieterii, wyzywającym stroju, albo nawet w gonieniu za mężczyznami, przekraczającym granice przyzwoitości i dobrego smaku ${ }^{39}$.

Pracy Kraffta-Ebinga sekundowali inni „znawcy przedmiotu”, m.in. Cesare Lombroso i Gugliemo Ferrero, autorzy Imbecillità morale in donna ladra e prostituta (1893), Remy de Gour-

${ }^{34}$ Dla Émila Durkheima świadomość zbiorowa to wytwór przeszłości, której autorytet związany jest z autorytetem tradycji (idem, De la division du tradition social, Paris 1960, s. 276-277). Kochanka Szamoty i W domu Sary to nie jedyne przykłady inspiracji Grabińskiego tradycją demonologiczną - innym jest Salamandra (1924). Punktem odniesienia do powieściowego związku Drzewickiego z Kamą jest XVIII-wieczna angielska ballada The Daemon Lover. Od konwencjonalnych realizacji motywu zakochanego upadłego anioła odróżnia powieść Grabińskiego natura Kamy: jest ona nie sukubem, lecz demonem ognia - tytułową salamandrą.

${ }^{35}$ K. Irzykowski, Stefan Grabiński, [w:] idem, Pisma rozproszone, red. A. Lam, t. 4, Kraków 1999, s. 154.

36 Była to twórczość bardzo często anonimowa, o której wartości świadczą "naukowe” tytuły, jakimi opatrywano dzieła krążące w tym obiegu: Siła sympatii, czyli wpływu duchowego na organizm ludzki i zwierzęcy jako środek w rozmaitych chorobach i przypadkach bardzo skuteczny z dodatkiem fizjonomicznych reguł i wskazówek, podług których szybko charaktery, temperamenta, zdolności i uczucia ludzi poznać można (Cieszyn 1890); Tajna szkoła magicznego cudotwórstwa, czyli książka prawdziwych praktyk odwiecznej boskiej magii, tak jak zostały objawione przez świętą Kabałę i Elohym, Weissensee p. Berlinem b.r.w. [pocz. XX w.].

37 O popularności wydawnictw propagujących „wiedzę tajemną" wspomina Janusz Dunin: "Nie tylko mieszczaństwo i znudzone «intelektualistki» prowincjonalne, ale i najwyższe sfery przedwojennej Polski pasjonowały się astrologią «naukową», okultyzmem i relacjami Stefana Ossowieckiego - inżyniera i jasnowidza" (idem, Papierowy bandyta. Ksiqżka kramarska i brukowa w Polsce, Łódź 1974, s. 140). Pośród adresatów owych sensacji nie zabrakło zapewne również i pisarzy.

${ }^{38}$ S. Grabiński, W domu Sary, s. 56-57.

39 R. von Krafft-Ebing, Zboczenia umysłowe na tle zaburzeń płciowych. Psychopathia sexualis, tłum. A. Fabian, Warszawa 1908, s. 210.

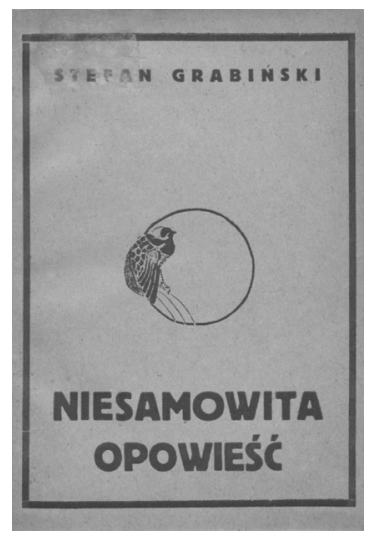

S. Grabiński, Niesamowita opowieść. (Wybór nowel), Wydawnictwo Dzieł Pogodnych, Lwów 1922 
mount w Fizyce mitości. Rzeczy o instynkcie płciowym (1903) oraz Paul J. Möbius w dziele O fizjologicznym niedorozwoju umystowym kobiety (1900). Poza pismami modnych w epoce filozofów i autorami prac paranaukowych, obraz kobiecości kształtowały również popularne w modernizmie psychologiczne analizy miłości, np. Miłość Maksa Nordaua (1903). Wypowiedzi te współbrzmiały $\mathrm{z}$ wizją społeczno-kulturowego statusu kobiety, promowanego na łamach periodyków. W prasie z epoki można było przeczytać m.in.:

Pamiętajmy, że kobieta posiada bez porównania więcej płciowości od nas; są takie, które są nią przepełnione, ona się z nich przelewa, ona właściwie jest siłą nieobliczalną, niepewna nawet w mężczyźnie, który jej podlega, a cóż dopiero w kobiecie, która jej podlega całe życie. Wyzwać taką istotę na logikę znaczy to samo, co rozprawić się z rzeką, która zerwała brzegi4 ${ }^{40}$.

Reprezentowana przez „słabą płeć” kobiecość uosabia w nowelistyce Grabińskiego to, co w związku mężczyzny i kobiety przekracza obyczajowe normy, stając się wyrazem perwer$\mathrm{sji}^{41}$. Twórca, na wzór modernistycznych poprzedników, postrzega relacje międzyludzkie jako źródło potencjalnego zagrożenia dla ładu społecznego ${ }^{42}$. Obecną $\mathrm{w}$ twórczości pisarza tendencję do utożsamiania erotyzmu z perwersją i wampiryzmem można odbierać jako wyraz związków jego pisarstwa z modernizmem europejskim. Być może należy też - co sugeruje Ewa Piasecka - upatrywać w fascynacji modernistycznych twórców fantastyki grozy (którzy szczególnie silnie oddziaływali na autora Demona ruchu) zauroczenia ekspresjonizmem; w nurcie tym biologizm kobiety postrzegano jako siłę irracjonalną ${ }^{43}$. Podobnie jak u twórców ekspresjonistycznych, w nowelistyce Grabińskiego dostrzec można połączenie pierwiastków skandalu obyczajowego z elementami irracjonalnymi, głównie związanymi $\mathrm{z}$ wprowadzeniem w obręb świata przedstawionego figury wampira ( $W$ domu Sary), sobowtóra (Problemat Czelawy, Czad) lub ożywionego trupa, wabiącego nieświadomą ofiarę ku zagładzie (Na wzgórzu róż, Kochanka Szamoty). Jedynie niekiedy - jak w noweli $W$ prze$d z i a l e$ - autor rezygnuje z wprowadzenia wątku nadprzyrodzonego na rzecz ukazania skrzywionej osobowości protagonisty, w niej upatrując źródeł transgresji obyczajowej. I wówczas jednak postać bohatera kreślona jest w taki sposób, by zaakcentować patologiczne cechy jego charakteru. W przywołanym tu utworze czytamy:

40 B. Lutomski, Kobieta i kobiecość, „Tygodnik Ilustrowany” 1901, nr 38, s. 738.

41 Interesującym „przełożeniem" na kod plastyczny jest traktowanie kobiety na przełomie XIX i XX wieku jako istoty łączącej w sobie pierwiastki ludzkie i zwierzęce. W modernistycznym malarstwie dość często pojawiają się kobiece ludzko-zwierzęco-demoniczne hybrydy, uosabiające pokusę grzechu, będącego wykroczeniem przeciw normom etycznym i obyczajowym. Przykładem służą obrazy Jacka Malczewskiego (np. Pokusa tortury, 1904) i Wojciecha Weissa (Wampir, 1899). Z malarstwa europejskiego, podejmującego analogiczną tematykę, na uwagę zasługują prace Franza von Stucka (Grzech, 1890-1891; Salome, 1906), Edwarda Muncha (Wampir, 1893-1894), Fernanda Khnopffa (Pustelnica, 1891; Pieszczoty, 1896), Jeana Delville'a (Pani Stuard Merrill, 1892).

42 Zob. uwagi Teresy Walas (Ku otchłani. Dekadentyzm w literaturze polskiej 1890-1905, Kraków 1986, s. 225-226) na temat modernistycznej obyczajowości: „Perwersja polega [...] zazwyczaj na tym, że bohaterowie nie znajdują zaspokojenia w tych formach związków uczuciowych, które są instytucjonalnie usankcjonowane [...]. Godne zaś pożądania staje się dla nich to właśnie, co zakazane, niedostępne i grzeszne. Za wyszukaną już realizację erotyzmu uchodzić więc będzie cudzołóstwo czy związek pozamałżeński".

43 E. Piasecka, „Dolina mroku”. Groza i niesamowitość w prozie polskiej lat 1890-1918, Opole 2006, s. 67. O fascynacji prekursorów ekspresjonizmu niemieckiego niesamowitością i grozą (na przykładzie kinematografii) Lotte H. Eisner (Ekran demoniczny, tłum. K. Eberhardt, Warszawa 1974, s. 29) pisze: „Mistycyzm i magia, ciemne siły, którym Niemcy zawsze ulegali z przyjemnością, natarły teraz z podwójną energią [...]. I upiory, które już nawiedzały niemieckich romantyków, znowu ożyły na podobieństwo cieni Hadesu, pokrzepiających się ludzką krwią". 
Tkwiło coś w istocie pędzącego pociągu, coś, co galwanizowało słabe nerwy Godziemby - podniecało silnie choć sztucznie nikłą energię życiową. [... ] Spotęgowane podniecenie utrzymywało przez czas trwania jazdy na sztucznej wyżynie wątte władze życiowe [...], by po ustąpieniu „szczęśliwych” warunków przejść w stan tym głębszej prostracji; pociąg w ruchu działał nań jak morfina, zastrzyknięta w żyły nałogowca ${ }^{44}$.

Być może dzieje się tak, ponieważ pisarz ten jest - według określenia Artura Hutnikiewicza - „mistrzem w wywoływaniu nastroju dziwności, poczucia niesamowitości świata i życia. Więc nawet te utwory, w których wszystko niby znajduje racjonalne wytłumaczenie, nawet one wyzwalają w nas utajony instynkt tajemnicy" (TLSG, s. 191).

W opowieściach aktualizujących wątek związku mężczyzny z „kobietą fatalną” nierzadko zostaje przekroczona granica dobrego smaku, ukazywane zaś sceny nabierają wydźwięku makabrycznej zabawy w nekrofilię:

Wyciągnąłem przed siebie rękę, chcąc ją objąć, i natrafiłem na obnażone biodra. Dreszcz przebiegł me ciało i krew zagrała gorącym warem. Po chwili piłem już słodycz jej łona. Była szalona. Zawrotna woń jej ciała odurzała zmysły, rozżarzała tęsknotę w płomień posiadania. Namiętny rytm jej boskich bioder podżegał pożar krwi i niecił szały... [...] Nagle przyszło mi na myśl, że obok na ścianie jest kontakt elektryczny. Ukląkłszy na łóżku, namacałem gałkę i przekręciłem. Bluznęło światło, rozświeciło pokój. [...] Przede mną w zgiełku koronek i atłasów leżał rozrzucony bezwstydnie, obnażony po linię brzucha kadłub kobiecy - kadłub bez piersi, bez ramion, bez głowy... ${ }^{45}$

Szczególnie wyraziście siła kobiecości - łącząca się z manifestacją sił nadprzyrodzonych pojawia się w tych nowelach, w których wykorzystana została figura wampira. W domu Sary, Czarna Wólka, Engramy Szatery to utwory, w których zaakcentowany zostaje erotyczny cha-

${ }^{44}$ S. Grabiński, W przedziale, [w:] idem, Demon ruchu, s. 31. Protagoniści nowel Grabińskiego stan analogiczny do tego, który stał się udziałem Godziemby, zdolni są osiągnąć nie tylko dzięki kontaktowi z wytworami cywilizacyjnymi. W Płomiennych godach (z tomu Księga ognia, Łódź 1922, s. 128) jeden z bohaterów "na widok pierwszych języków ognia nagle jakby przeistoczył się cały. Jakieś nieznane siły napływać zaczęły w jego dotąd chłodne, zrównoważone jestestwo, jakieś prądy gorące, zapędne zaczęły kipieć w żyłach".

${ }^{45}$ S. Grabiński, Kochanka Szamoty. (Kartki ze znalezionego pamiętnika), [w:] idem, Niesamowita opowieść, s. 21-22. Interesujące jest zestawienie przywoływanego tu fragmentu z twórczością modnego ówcześnie i postrzeganego jako pisarza skandalizującego Hannsa Heinza Ewersa. Jako reprezentatywny dla tego twórcy przywołajmy opis Wenecji: „Rozpalona, zgniła woda kanałów cuchnęła, pełno brudów pływało naokoło. Komary i ćmy w niesłychanych ilościach unosiły się ponad tym i niby delikatnym całunem pokrywały powierzchnię wody. Wysoko po obu stronach wznosiły się pałace, w posępnym świetle latarni świeciły jak nagie czaszki trupie. Wspaniałe fasady, które za dnia kłamią pozory życia [...]. Jakaś gondola nadjechała naprzeciw czarna, pływająca trumna jak wszystkie inne. Tylko że była pokrytą, a pod czarnym baldachimem siedziała przytulona do siebie jakaś młoda para. [...] Czyż nie było to jakby żądza rozrodcza robactwa trupiego stawała się gorętszą w tej rozkładem ciężarnej atmosferze?" (idem, Uczeń czarnoksięski, tłum. J. Przybyszewska, Lwów 1919, s. 348-349; zob. opis finału zalotów bohatera do uwięzionej w lodzie księżniczki w: idem, Koniec Johna Hamiltona Llewellyn, tłum. S. Przybyszewski, [w:] idem, Serca królów, Lwów 1922, s. 126). Jakkolwiek sam Grabiński odżegnywał się wielokrotnie od fascynacji Ewersem (np. w szkicu O twórczości fantastycznej), trudno nie dostrzec w obu wypadkach zainteresowania makabrą dla niesionego przez nią efektu artystycznego. Podobna do estetyki jest etyka, jaką kierują się niektórzy bohaterowie Grabińskiego (np. Stachur z Problematu Czelawy lub Kuźma Żębroń z Lepianki w czystym polu (1933)). Krystyna Kamińska, pisząc o krótkich formach prozatorskich Ewersa, zauważa, że ich protagoniści funkcjonują w układach społecznych, odbiegających od obowiązujących powszechnie norm moralnych, przedkładając nad moralność konsekwencję w dążeniu do realizacji własnych celów (eadem, Fantastyczny świat opowiadań Ewersa, „Nowe Książki” 1992, nr 12, s. 52). Oczywiście nie należy poszukiwać nazbyt daleko idących analogii między pisarstwem Grabińskiego i Ewersa; rację ma Karol Irzykowski: „Ewers jest wyrafinowany, perwersyjny, zdąża zwykle do jednej końcowej niezwykłej sytuacji, do jednego efektu, a zresztą bywa i nudny. Grabiński jest głębszym, włada lepiej środkami napięcia i nastroju i w ogóle jako autor jest uczciwszy" (idem, Stefan Grabiński, [w:] idem, Pisma rozproszone, red. A. Lam, t. 1, Kraków 1998, s. 443; zob. TLSG, s. 235). 
rakter więzi łączącej wampira i jego ofiarę ${ }^{46}$. W noweli $W$ domu Sary akt samoofiarowania bohatera wampirowi ukazany jest jako zwieńczenie miłości:

Pewnego pięknego dnia spotykasz wyjątkową kobietę, uosobienie płci, i odtąd, od pierwszego z nią stosunku, nie możesz się z nią rozstać. Nienawidzisz jej, rad byś zrzucić kajdany, lecz wysiłki są nadaremne. Jesteś opętany jej płcią najzupełniej; cały widnokrąg myślowy zamyka się wyłącznie w kole jej ciała, jej kształtów, spojrzeń, dotknięć, obcowanie fizyczne z nią staje się formą bytu. Kobieta przeradza się w bożyszcze złe i nienawistne, niemniej ponętne, któremu musisz ulegać bezwzględnie ${ }^{47}$.

Poszukując nowych sposobów wzbudzania grozy (co stanowiło odzwierciedlenie postulatów Grabińskiego teoretyka w twórczości Grabińskiego pisarza), autor odwołuje się do tradycji powieści gotyckiej, ujawniającej mroczną stronę egzystencji człowieka. Zdaje się w tym naśladować Edgara Allana Poego, piszącego w jednym z sonetów:

Są takie bezcielesne rzeczy, są zjawiska,

Co byt mają podwójny, jak bliźnięca owa

Moc, co naraz z materii i ze światla tryska -

I naraz tworzy bryłę i cień w sobie chowa ${ }^{48}$.

Źródeł akcentowanej przez Poego dwoistości świata Grabiński zdawał się - na wzór Amerykanina - upatrywać w przenikaniu elementów racjonalizmu i spirytyzmu ${ }^{49}$. Przed Freudowsko rozumianą „niesamowitością” (das Unheimliche) nie chroniła człowieka ani natura, będąca ostoją sił nadprzyrodzonych, ani technika, ponieważ wytwory tejże mogły zostać opętane przez byty irracjonalne. Technika zresztą - zwłaszcza kolej, której Grabiński poświęcił tom Demon ruchu - to przestrzeń konfrontacji racjonalizmu i nadprzyrodzonego.

${ }^{46}$ W przywołanych tu nowelach Grabińskiego, podobnie jak we wcześniejszej Pogance Narcyzy Żmichowskiej, kochankowie stają się ofiarami niszczącej namiętności. Kobiecość i związana z nią płciowość u obojga twórców jest atutem kobiety-wampira, kuszącej ofiarę pozorem urody (B. Zwolińska, op. cit., s. 136-139). Kobiecość jako siła fatalna, służąca podporządkowaniu mężczyzny, uwypuklona została zwłaszcza w Kochance Szamoty, której protagonistkę narrator kreuje na istotę niezwykłą, posługując się kulturowymi cliché. Egzotyczny strój (peplos) i osobliwe zwyczaje podkreślają ekscentryzm jej zachowania, potęgując nastrój tajemnicy (K. Kłosińska, Fantazmaty. Grabiński - Prus - Zapolska, Katowice 2004, s. 25). Dla akcentowanej przez Kłosińską tajemniczości, jako zasadniczego rysu kreacji Jadwigi Kalergis, można znaleźć punkt odniesienia w postaciach kobiecych w nowelistyce Poego. Martin Bickman, podążając Jungowskim tropem „kobiety-Sfinksa”, traktuje je jako istoty owiane numinotyczną aurą, kryjącą w sobie tyleż obietnicę wtajemniczenia w "wiedzę" niedostępną zwykłym śmiertelnikom, co zagrożenie śmiercią i rozpadem (idem, The Unsounded Centre. Jungian Studies in American Romanticism, Chapel Hill 1980, s. 59).

47 S. Grabiński, W domu Sary, s. 57-58. Wspomnianej mocy Sary doświadcza również protagonista noweli. Znamienne, że siłę, umożliwiającą mu pokonanie uroku kobiety, czerpie z zewnątrz, niezdolny własną mocą do przełamania pokus związanych z Sarą.

${ }^{48}$ E. A. Poe, Milczenie, tłum. A. Lange, [w:] idem, Poezje, red. P. Marszałek, Toruń 1996, s. 23.

49 Andrzej Kopcewicz i Marta Sienicka (Edgar Allan Poe i Sidney Lanier, [w:] iidem, Historia literatury Stanów Zjednoczonych w zarysie. Wiek XVII-XIX, Warszawa 1983, s. 196) celnie zauważają, że w twórczości Poego "cała fizyczna, empiryczna rzeczywistość, którą przyzwyczailiśmy się uważać za prawdę, jest zaledwie zmysłowym złudzeniem. Czas i przestrzeń stwarzają pozory obiektywizmu i jeżeli w ogóle istnieją, co Poe podaje w wątpliwość, są wartościami subiektywnymi i narzucają wyobraźni człowieka nierealny obraz świata. [...] Prawdziwa rzeczywistość to dostępna ludzkiej intuicji sfera wyobraźni - wymiar przeciwstawny czasowo-przestrzennym ograniczeniom - w której nie obowiązują znane nam prawa życia i śmierci. Strefa ta [...] sprawdza się w urojonych halucynacyjnych obrazach powstających w podświadomej wyobraźni lub wizjach człowieka, gdy jego wola znajduje się na granicy snu i jaźni". 
Potrafi ona - w Maszyniście Grocie, W przedziale i Wiecznym pasażerze - „opętać” głównych bohaterów tak, iż wytwór techniki zaczynał dominować nad osobowością postaci ${ }^{50}$. W pierwszej z przywołanych tu nowel Grabiński zawarł obraz pędzącej na zatracenie lokomotywy, która zdaje się stanowić jedność z maszynistą:

Maszyna rozpętała się. Obłąkane chyżością koła wykonywały nieuchwytne, fantastycznie chybkie obroty, uznojone tłoki cofały się, to znów parly w przód skwapliwym gestem, tłukły się opętańczo zziajane kolby. Wskazówka na manometrze szła wciąż w górę - rozżarzony do czerwoności kocioł zionął skwar, przepalał skórę, parzył dłonie. Nic to! Prędzej! [...] Wtem ... zakotłowało się coś, zawyło szatańskim skowytem - rozległ się huk [...]. Wytrysnął w górę ognisty, splątany kłąb, zgmatwany słup odłamków, żelaznych skorup, pogiętych blach - prysnęła pod niebo rakieta szczątków, rozprutych przęseł, rozpękłych dzwon ... ${ }^{51}$

Zderzenie tego, co można objąć rozumowo, i wykraczającego poza zdrowy rozsądek sygnalizuje umiejscowienie fabuły w przestrzeni nacechowanej semantycznie. Ma ona podwójną funkcję: nie tylko umożliwia lokalizowanie miejsca i czasu akcji, lecz - przede wszystkim - pozwala na egzotyzację doświadczenia lekturowego odbiorcy. Jakkolwiek bowiem dworzec kolejowy, bocznica, stary dom to elementy znane czytelnikowi spoza lekturowych doświadczeń, w nowelistyce autora Demona ruchu zyskują nowy wymiar, poprzez wskazanie na szczególne aspekty ich funkcjonowania w obrębie świata przedstawionego. Przykładem służy bocznica kolejowa z Gluchej przestrzeni. Jest ona nie tylko (i nie przede wszystkim) wyłączonym z użytkowania - wskutek melioracji bagien - odcinkiem toru kolejowego, lecz również stacją, na którą zajeżdża pociąg widmo, aby zabrać dozorującego ją dróżnika. Staje się miejscem nawiedzonym, tak jak w konwencjonalnej fantastyce grozy opuszczone domostwo, ewokując analogiczny nastrój niesamowitości.

Inspirowana romantyczną tradycją egzotyka bywa aktualizowana w różnoraki sposób, nie tylko jako obnażanie ukrytego wymiaru codzienności (jak w wypadku infrastruktury kolejowej $)^{52}$. Interesującym przykładem wykorzystania stereotypowych, wywodzących się $\mathrm{z}$ romantyzmu wyobrażeń na temat Wschodu jako przestrzeni niezbadanej jest utwór Grabińskiego Jak Myriam odeszła (1921). Miejsce akcji, bliżej nieokreślone arabskie miasto,

50 Jest to motyw, którego konwencjonalną wersję Grabiński wykorzystuje w noweli Szalona zagroda z debiutanckiego tomu $Z$ wyjątków. W pomrokach wiary. W utworze tym „przeklęte miejsce” zaczyna przejmować kontrolę nad bohaterem, doprowadzając do tragedii.

51 S. Grabiński, Maszynista Grot, [w:] idem, Demon ruchu, s. 102. Demoniczny wpływ kolei nie ograniczał się zresztą jedynie do pracowników. W noweli $W$ przedziale główny bohater uwodzi przypadkowo spotkaną kobietę, jej męża zaś zabija, a w humoresce Wieczny pasażer bohaterem jest człowiek zafascynowany kolejnictwem, który wdziera się do każdego pociągu, by następnie z niego wysiąść. Podobnie jak w wypadku „technologiczno-gotyckich" krajobrazów, również w ukazaniu wzniosłości ruchu istotny kontekst stanowi dzieło Edmunda Burke'a (idem, Dociekania filozoficzne o pochodzeniu naszych idei wzniosłości i piękna, tłum. P. Graff, Warszawa 1968). Jakkolwiek powstałe w połowie XVIII wieku (a więc przed okresem eksplozji technologicznej, która przypadała na drugą połowę XIX w.), Dociekania filozoficzne... mogą stanowić ważki kontekst filozoficzny dla rozważań o wzniosłości techniki, o czym świadczą słowa Anette Freitag, akcentującej szybkość jako funkcję nowoczesnego doświadczenia ruchu, porządkującego na nowo wyobraźnię społeczną (zob. eadem, When the Railway Conquered the Garden. Velocity in Parisian and Viennese Parks, [w:] Landscape Design and Experience of Motion, ed. M. Conan, Washington 2003, s. 215).

52 Pisząc o egzotyce, Andrzej Stoff (Egzotyka, egzotyzm, egzotyczność. Próba rozgraniczenia pojęć, [w:] idem, Studia z teorii literatury i poetyki historycznej, Lublin 1997, s. 217) zauważył: „Mamy do czynienia z historyczną zmiennością lokalizacji egzotyki, przy czym chodzi tu nie tylko o umiejscowienie geograficzne, ale i w różnych sferach rzeczywistości". 
uosabia to wszystko, czym dla romantyków był Orient, traktowany jako miejsce cudowne: tajemniczość, nieracjonalność mądrości i pogodzenie przeciwieństw ${ }^{53}$. Charakterystyczny dla romantycznego postrzegania Orientu jest w tym utworze zarówno erotyzm sytuacji (tytułowa protagonistka oczekuje na ślub, od którego oddziela ją jedynie noc), jak i łączenie motywu miłości z okrucieństwem wobec siebie (Miriam decyduje się odejść od ukochanego do kolonii trędowatych, gdy dowiaduje się, że w ten sposób ocali go przed śmiercią) $)^{54}$. Z kolei w Podzwonnym (1909) taniec Kreolki jest pretekstem do ukazania jej zmysłowości.

Niekiedy też irracjonalne zdarzenia ukazane są, niczym w noweli Ultima Thule (1919) lub Dziwnej stacji (1919), w scenerii sugerującej pogranicze między różnymi wymiarami czasoprzestrzennymi ${ }^{55}$. Przestrzeń ulega wówczas stereotypizacji tak, aby ukazać napięcie między dominującą naturą a elementami jej obcymi, stanowiącymi wtręt w kreowaną dzięki poetyce wzniosłości - wizję majestatycznych krajobrazów:

Okolica Szczytnisk była dziwnie piękna. [... ] Zdradzała zasadniczo odrębny i swój charakter, jakiego nie spotykało się nigdzie w tych stronach. Malutki budynek stacyjny, przytulony do potężnej, granitowej ściany spadającej prostopadle w dół, przypominal jaskółcze gniazdo, przypięte do wnęki skalnej. Wokoło spiętrzone na $2000 \mathrm{~m}$ szczyty grążyly w półmroku przestrzeń, stację i magazyny. Posępny smutek zwiany z czół olbrzymów owijał nieuchwytnym całunem kolejową przystań. W górze kłębiły się wieczne mgły i staczały w dół turbanami mokrych oparów. [...] Parę zaskórnych strumieni, zbratawszy się potajemnie w trzewiach góry, biły z jej boku tęczowym lukiem siklawy ${ }^{56}$;

Przestrzeń kolejowa, na której odpoczywal „Infernal”, była wąskim parowem wciśniętym pomiędzy dwie pierzeje prostopadłych niemal, dziko nawisłych skalnych ścian, strzelających w niebo

${ }^{53}$ Zob. Słownik literatury polskiej XIX wieku, red. J. Bachórz, A. Kowalczykowa, Wrocław 1991, s. 657, hasło: Orientalizm. Być może fascynacja mistyką Orientu miała źródło w zauroczeniu ogromem tamtejszej przestrzeni. Józef Bachórz zauważa, że w konfrontacji z Europą wschodnie krainy wydawały się przestrzenią wszechmożliwości (idem, O polskim egzotyzmie romantycznym, [w:] Problemy polskiego romantyzmu, red. M. Żmigrodzka, Wrocław 1974, s. 269).

${ }_{54}$ Traktowanie Wschodu jako przestrzeni nacechowanej erotyką związane było w romantyzmie z odmiennością obyczajów. Aura erotycznej zmysłowości dla pokolenia filomackiego związana była z fascynacją kobietami Wschodu, na które chętnie kreowano wówczas własne wybranki (zob. A. Zajączkowski, Orient jako źródło inspiracji w literaturze romantycznej doby mickiewiczowskiej, Warszawa 1955, s. 74). Z czasem jednak fascynacja kobiecością mieszkanek Wschodu uległa stereotypizacji, w której na plan pierwszy wysunęła się sugestywność ich obrazowania. Obraz Wschodu w utworach Grabińskiego zakorzeniony jest w takim właśnie ustereotypowionym jego postrzeganiu. Innym sygnałem fascynacji Grabińskiego Orientem jest sięganie przezeń (w Kochance Szamoty) do elementów „kultury haremu” (termin Krystyny Kłosińskiej, op. cit., s. 31-32). Kłosińska mianem tym określa specyficzną dla bliskowschodniej erotyki tabuizację określonych sfer ciała kobiety, werbalizowaną w noweli Grabińskiego takim aranżowaniem spotkań kochanków, by mężczyzna nie mógł objąć wzrokiem całej postaci bohaterki. Zob. opinię Reinholda Dorrzapha na temat erotyzmu wschodniego: „Przyzwoitość nakazuje, aby mając przed sobą kobietę, którą wybrali na noc, patrzyli jedynie na jej twarz. Jeśli wzrok przesunie się niżej [...] mężczyzna wierzący musi liczyć się z konsekwencjami: od tej pory jego oczy są przeklęte" (idem, Eros, małżeństwo, Lucyper w pludrach. Dzieje obyczajowości seksualnej, tłum. M. Dutkiewicz, Gdynia 1997, s. 74). W wypadku noweli Grabińskiego mamy do czynienia z sytuacją à rebours: to twarz pozostaje tabuizowana, a wzrok Szamoty obejmuje jedynie wybrane atrybuty kobiecości.

${ }_{55}$ Tendencja do podważenia jednoznaczności ontologii świata przedstawionego jest charakterystyczna dla całej fantastyki grozy. Marek Wydmuch uzasadnia ją następująco: „opowieść grozy [...] zamiast tworzyć nowy świat, decyduje się na opatrzenie świata realnego innym, własnym znakiem [...] [jej] siła [...] tkwi właśnie w konfrontacji znanego świata z nowym jego sensem. Angażuje to uwagę czytelnika w dwójnasób, gdyż ustawia go na granicy dwóch porządków w taki sposób, by na moment mógł zapomnieć, który z nich jest rzeczywisty" (idem, Gra ze strachem, Warszawa 1975, s. 171). Beletrystykę Grabińskiego odróżnia jednakże od konwencjonalnej opowieści grozy poszukiwanie irracjonalnej wykładni w zjawiskach codziennych. Charakterystyczna dla tej tendencji jest nowela Cień (z tomu Na wzgórzu róż, Kraków 1918), której pierwszoosobowy bohater, a zarazem narrator, tworzy „ontologię cienia”, eksponując jego wymiar nadprzyrodzony.

${ }^{56}$ S. Grabiński, Ultima Thule, [w:] idem, Demon ruchu, s. 171. 
na jakie 3000 metrów. Do stóp jednego z tych olbrzymów przywarł dworzec. [...] Wyskakujące ze zbocza góry dwa okrutne wiszary, dwie drapieżne łapy tytana zaciążyly nad stacją, grożąc bezwzględną zagładą ${ }^{57}$.

Punktem odniesienia dla przywołanych fragmentów, motywującym wybór górskiej scenerii akcji, są uwagi Edmunda Burke’a na temat relacji między wielkością przedmiotu a wzbudzanymi w obserwatorze wrażeniami. Autor Dociekań filozoficznych... zauważał, że wielkość może być źródłem uczucia wzniosłości, wiążącej się z przedmiotami wielkimi i straszny$\mathrm{mi}^{58}$. Góry w europejskiej tradycji kulturowej stanowily też miejsce uświęcone, umożliwiające doświadczenie transcendencji ${ }^{59}$. Jako przestrzeń odosobniona, pozwalały na kontakt ze sferą nadprzyrodzoną, której manifestacje (w tomie Demon ruchu związane były one ze znikaniem ludzi i pociągów) wprowadzały element irracjonalny. Artur Hutnikiewicz, pisząc o roli przestrzeni świata przedstawionego w kreowaniu nastroju czytelnika, zauważył:

Krajobraz wprowadza nas niejako z miejsca w pożądany nastrój opowieści, zanim rozpoczął autor rzecz właściwą. Opis ten stwarza klimat, stwarza atmosferę sposobną i podatną dla przyjęcia wydarzeń, które nastąpią. Jeszcze nie wiemy, co się stanie, a już przeczuwamy, że mogą się tu zdarzyć tylko rzeczy niezwykłe, rzeczy niesamowite, tak jak niesamowicie piękny i groźny zarazem jest krajobrazowy sztafaż [TLSG, s. 372].

Jednakże w tomie Demon ruchu bohater doświadcza transcendencji nie tylko dzięki właściwości otaczającej go przestrzeni, lecz również w akcie podróżowania koleją ${ }^{60}$.

Niekiedy rozwój fabuly w kierunki ingerencji sił nadprzyrodzonych bywa w nowelistyce Grabińskiego sygnalizowany - jak w Dziwnej stacji - obecnością pośród bohaterów wschodniego mędrca. Jako jedyny potrafi on zrozumieć rozgrywające się wypadki i staje się przewodnikiem duchowym w nowym, wyższym wymiarze egzystencji bohaterów. Postać Hindusa (lub bohatera pełniącego analogiczną funkcję) to pogłos modernistycznej powieści okultystycznej, której protagonista dostępuje inicjacji w arkana wschodniej magii. Niczym w Wampirze Władysława Reymonta (1911) lub Starej Ziemi Jerzego Żuławskiego (1911), wschodni mędrzec w noweli Grabińskiego jest zarazem przewodnikiem i krytykiem europejskiej duchowości. Obecność tej postaci umożliwia też autorowi wprowadzenie modnego tak w modernizmie, jak i w międzywojniu tematu spirytyzmu. Jako wyraz wiary w potęgę jasnowidzenia, a zarazem deklarację ideową Grabińskiego, można odczytywać jedną z jego młodzieńczych nowel, Puszczyka (1909). Bohater utworu, włóczęga obdarzony możliwością prekognicji, doświadcza integralności z Kosmosem dzięki zawieszeniu władzy rozumu i zmysłów na rzecz intuicji:

Dziwne sny miałem - marzenia, których podobno zwykły sen nie użycza. Miałem wrażenie czegoś nieokreślonego, ogromnie wiotkiego, co przenikało wszechświat, przepływało całą mą istotę, łącząc ją ściśle z olbrzymim środowiskiem ziemi. Gibkie, prężne fale ciekły przez ciało,

${ }^{57}$ Idem, Dziwna stacja. (Fantazja przyszłości), [w:] idem, Demon ruchu, s. 130-131.

${ }^{58}$ E. Burke, op. cit., s. 129. Na temat roli ogromu we wzbudzaniu odczucia wzniosłości zob. s. 81-82.

59 J. Woźniakowski, Góry niewzruszone. O różnych wyobrażeniach przyrody w dziejach nowożytnej kultury europejskiej, Kraków 1995, s. 63-151.

60 W. Tomasik, Ikona nowoczesności. Kolej w literaturze polskiej, Wrocław 2007, s. 29. 


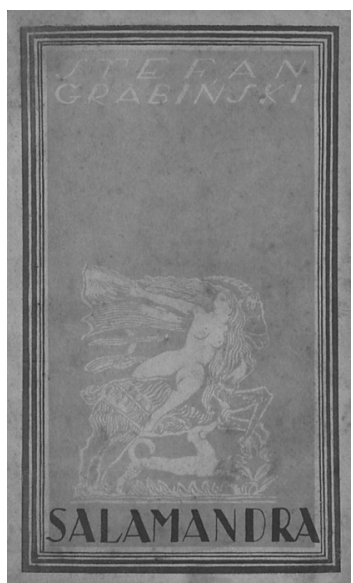

S. Grabiński, Salamandra. Powieść fantastyczna, Wydawnictwo Polskie, Poznań-Lwów [1924] a w nich jakieś ruchy subtelne jak myśl, elastyczne jak piłka mrzały... Odczuwałem je, lecz nie zmysłami - te spały snem żelaznym, nieprzepartym - odczuwałem całym sobą, najdrobniejszymi włóknami nerwów, ich splotem tysiącwęzłowym rozpięty w ciele [...] I rozumiałem! Ja - człowiek - wiedziałem! ${ }^{61}$

Wraz ze spirytyzmem pojawia się w twórczości Grabińskiego kwestia metempsychozy (najbardziej wyrazistą postać przybiera ona w powieści Wyspa Itongo z 1936 roku w wątku zbieżności dat śmierci inżyniera Śląskiego i narodzin Gniewosza). Jest to temat nieobcy twórcom romantycznym i modernistycznym oraz tym, którzy w okresie międzywojennym odwoływali się do tradycji młodopolskiej. Metempsychoza jako temat literacki była wyrazem fascynacji ex oriente lux: Antoni Lange reinterpretuje motyw reinkarnacji m.in. w opowiadaniu Rozaura Montalboni (1911), a Karol Gjellerup w 1928 roku publikuje „romans metafizyczny" Wędrowcy światta, którego treścią są zdarzenia składające się tyleż na historię rozgrywającą się współcześnie, co i przed dwoma tysiącami lat ${ }^{62}$.

Obecności podobnych - co wykorzystywanych w twórczości Langego i Gjellerupa - motywów w beletrystyce Grabińskiego upatrywać można jednak nie tylko jako wyrazu ducha epoki ${ }^{63}$. Sięga on bowiem nie tyle po młodopolskie i późniejsze artystyczne opra-

61 Puszczyk, [w:] S. Żalny, Z wyjątków, s. 10-11. Słowa głównego bohatera noweli można traktować jako artystyczną interpretację teorii Jana W. Dawida, upatrującego w sztuce wyrazu doświadczenia mistycznego: „Każdy prawie ma w życiu chwile, w których do powszedniej, rozumowej świadomości jego przenikają jakieś błyski innego, irracjonalnego porządku rzeczy, jakieś przeczucia, lęki, uniesienia, natchnienia, impulsy, prawie wizje jakichś prawd" (idem, O intuicji w mistyce, filozofii i sztuce, Kraków 1913, s. 25). Tendencję do odrzucania racjonalnej wykładni rzeczywistości w sztuce przełomu XIX i XX wieku można traktować jako wyraz potrzeb ówczesnej świadomości społecznej. Juliusz Kleiner (Zarys dziejów literatury polskiej, t. 2, Lwów 1939, s. 204) akcentował rangę sił irracjonalnych dla kreacji wizji człowieka w literaturze jako przeciwwagi dla pozytywistycznego determinizmu przyrodniczego. Rangę tendencji do irracjonalnej wykładni rzeczywistości dla pisarstwa Grabińskiego akcentuje m.in. Małgorzata Zamojska (Demon ruchu w szponach kognitywizmu - analiza i interpretacja porównawcza utworów "W przedziale” oraz "Wieczny pasażer" Stefana Grabińskiego, „Verte. Krytyczny Magazyn Internetowy" 2006, nr 21, http://stare.verte.art.pl/literatura/demonruchu [dostęp: 21.03.2013]). Być może jednak istotniejszym, niż opozycja wobec determinizmu przyrodniczego pozytywizmu, punktem odniesienia dla kreślonych przez Grabińskiego obrazów odmiennych stanów świadomości jest romantyczny kult szaleństwa. Maria Janion zauważa, że w epoce tej w obliczu silnie doświadczanego kryzysu egzystencjalnego poszukiwano sposobów jego manifestacji. Jedną z metod stał się wówczas język szaleństwa jako próba odpowiedzi na dylematy egzystencjalne inną drogą niż ta wytyczona przez rozum (eadem, Projekt krytyki fantazmatycznej. Szkice o egzystencjach ludzi i duchów, Warszawa 1991, s. 9). Zob. uwagę Michela Foucaulta na temat postrzegania relacji między szaleństwem i prawdą w pierwszej połowie XIX wieku: „w obłędzie człowiek upada w prawdę o sobie; a jest to sposób całkowitego się z nią utożsamienia i równocześnie jej utracenia. Obłęd nie będzie już mówił o niebyciu, ale o byciu człowieka, o treści tego, czym on jest i o tej treści traceniu. [...] I w ten sposób podwaja się u obłąkanego moc atrakcji i fascynacji: prawdy, które przynosi, przerastają go" (idem, Historia szaleństwa w dobie klasycyzmu, tłum. H. Kęszycka, Warszawa 1987, s. 463). Zgodnie z tym szaleństwo zaostrza zmysły bohaterów nowel Grabińskiego, zarazem jednak wzbudzając wątpliwość co do realności ich przeżyć. W ten sposób prawda o świecie zostaje przez protagonistów odkrywana i zarazem gubiona.

62 Filozoficzno-socjologicznym kontekstem, być może wyjaśniającym fascynację twórców metempsychozą, są słowa Piotra Chmielowskiego, wyrażające przekonanie o determinizmie historii, którą należy rozpatrywać jako zjawisko analogiczne do procesu przyrodniczego: „Nie idzie [...] tu o jakieś nieubłagane fatum albo ślepą konieczność, ale ów rozwój dziejowy, który według nas od ściśle oznaczonych przyczyn zależy; gdyż to uznać musimy jako fakt, że i w życiu duchowym istnieje przyczyna i skutek, że każdy następujący stan umysłowo-moralny jest koniecznym produktem poprzedzającego” (idem, Statystyka i moralność, „Przegląd Tygodniowy" 1871, nr 50, s. 414).

63 W tej perspektywie można odczytywać studium Maurycego Maeterlincka z zakresu parapsychologii pt. Śmierć z 1913 roku (pol. tłum. H. Czarkowska, Poznań 1921). To jednak, co w modernizmie można było uznać za poszukiwanie nowego sposobu odczytania świata (mediumizm, parapsychologia, spirytyzm), w międzywojniu przeszło w sferę kultury popularnej. Bruno Winawer w żartobliwy sposób pisał: „Na seansach spirytystycznych wygadują takie bzdurstwa, że sprzykrzyły się nawet starszym paniom i bladym panom z małego kółka «wtajemniczonych»" (idem, Bajeczki wigilijne, [w:] idem, 300000000 koni, Warszawa 1935, s. 16). 
cowania wątków reinkarnacji, co po romantyczną twórczość Poego, w którego nowelistyce pojawia się dość często motyw wędrówki dusz; przykładem służy m.in. Metzengerstein (1832), Morella (1835), Ligeja (1838) ${ }^{64}$. Można zauważyć zbieżność metody amerykańskiego mistrza fantastyki grozy i Grabińskiego: nowelę Tajemnica hrabiego Maspery (1930) zbliża do twórczości Poego pogłębienie wizerunków postaci tak, iż uwaga czytelnika zostaje przeniesiona $\mathrm{z}$ sensacyjnej fabuły na rys psychologiczny bohaterów (analogicznie motyw metempsychozy Grabiński wykorzystał - prócz wspomnianej Wyspy Itongo - również w powieści Klasztor i morze, 1928).

Bohaterowie utworów Grabińskiego dość często obarczeni są jakąś wadą lub anomalią fizjologiczną bądź psychiczną ${ }^{65}$. Ta ich właściwość sprawia, że postrzegają zjawiska zakryte przed zwykłymi ludźmi. To - rozumiani antropologicznie - „odmieńcy”, funkcjonujący na pograniczu dwu światów: codziennej pracy i mistycznych dociekań nad naturą świata i rzeczywistości. Niedookreśloność ich statusu ontologicznego podkreśla wygląd zewnętrzny; tytułowa postać Czerwonej Magdy (1922) zwraca uwagę efemerycznością, przywołującą na myśl kulturowe wyobrażenia istot demonicznych ${ }^{66}$ :

Wysoka, wątła i blada, zwracała uwagę dużymi czarnymi, wiecznie w przestrzeń zapatrzonymi oczyma i ruchami rąk, których nigdy opanować nie umiała. Ręce te, równie blade jak twarz, przebiegały ustawicznie jakieś nerwowe dreszcze czy skurcze, wywołując niespokojny, spazmatyczny ruch palców - długich, wąskich, wiecznie zimnych. Włosy miała bujne, czarne, które w lśniąco kruczo wężach wymykały się spod jedwabnej, ognistopomarańczowej chusty, jedynej ozdoby ${ }^{67}$.

Zgodnie z inspirowaną jarmarcznymi opowieściami fizjonomiką, odmienność ducha manifestowana jest szczególnym wyglądem zewnętrznym bohaterów oraz ich ekscentrycznym zachowaniem (Magda ze wspomnianej noweli wznieca pożary swą obecnością). Niekiedy, jak w Spojrzeniu (1922), zdolni są oni przeczuć istotę rzeczywistości, lecz wiedzę tę przypłacają życiem:

W jakiś jesienny wieczór, siedząc nad otwartą książką, nagle wyczul poza plecyma „to”. Coś działo się tam poza nim: rozsuwały się tajemnicze kulisy, dźwigały w górę kotary, rozchylały się fałdy draperii ... [...] Ruchem naglym jak myśl, jak blyskawica oglądnął się i spojrzał. I wtedy z ust

${ }^{64}$ Grabiński znał przywołane tu utwory Poego zapewne z edycji w tłum. Stanisława Wyrzykowskiego pt. Arabeski (1922); jeśli zaś zapoznał się z nimi później, uczynił to przed rokiem 1931, kiedy ogłosił poświęcony Poemu szkic Książę fantastów. Możliwe również, że zapoznał się z nowelistyką Poego jeszcze wcześniej, dzięki licznym przekładom pojawiających się na łamach polskiej prasy już od początków modernizmu - zob.: F. Lyra, Edgar Allan Poe, Warszawa 1973 (tu zestawienie Polskie przekłady dzieł Poego, s. 354-373).

${ }^{65}$ Na przykład: protagonista Na wzgórzu róż obdarzony jest nadnaturalnie wrażliwym węchem; tytułowy bohater Maszynisty Grota pozwala, by owładnął nim pęd lokomotywy, bez względu na konsekwencje; Wrzecki z Po stycznej jest niezrównoważony psychicznie, Olivarez z Wampira - marząc o życiu wiecznym - popełnia samobójstwo, dzięki któremu przeistacza się w istotę egzystującą na pograniczu życia i śmierci; Godziembę z W przedziale ożywia ruch pociągu, wprowadzając w czasie postojów w stan prostracji; bohater Szalonej zagrody to były pacjent szpitala psychiatrycznego; Czarnocki z Zemsty żywiołaków przejawia zdolności metempsychozy, a Kobierzycki z Płomiennych godów jest piromanem, zdolnym do uniesień erotycznych jedynie po wznieceniu pożaru.

${ }^{66}$ A. Gemra, Piękna pani i lord o bladych licach: transformacja opowieści o wampirach w tekstach grozy, [w:] Podanie - legenda w tradycji ludowej i literackiej, red. M. Jakitowicz, V. Wróblewska, Toruń 2007, s. 227-244.

${ }^{67}$ S. Grabiński, Czerwona Magda, [w:] idem, Księga ognia, s. 6. 
jego wyszedł nieludzki krzyk grozy i strachu bez granic; konwulsyjnie chwycił się ręką za serce i jak piorunem rażony zwalił się bez życia na posadzkę pokoju ${ }^{68}$.

Za sprawą spaczonej osobowości protagonistów noweli Grabińskiego w przestrzeń świata przedstawionego wdziera się pierwiastek irracjonalny, podważający rozumową wykładnię zdarzeń. Nawet bowiem jeśli - jak w tomie Demon ruchu - mamy do czynienia z opowieściami, których akcja rozgrywa się w przestrzeniach kojarzonych ówcześnie z nowoczesnością, bohaterami pozostają osobnicy wyalienowani ze społeczeństwa - głównie za sprawą niekonwencjonalnego rozumowania lub cech charakteru postrzeganych przez ogół jako ułomność psychiczna lub emocjonalna ${ }^{69}$.

Czytelnik, dzięki temu zabiegowi - polegającemu na osadzaniu inspirowanych literaturą grozy „ludzi ze skazą” (przykładem figura łotra gotyckiego) w znanej mu z codziennego doświadczenia scenerii - ma poczucie, że postaci Grabińskiego funkcjonują w przestrzeni gotyckiej. Jest ona w szczególny sposób poddana zabiegom aktualizującym, które - jak w Demonie ruchu - polegają na jej „stechnicyzowaniu”70. Szczególnie wiele miejsca Grabiński poświęcał dworcom i bocznicom kolejowym - zarówno funkcjonującym, jak i pozbawionym znaczenia „bocznym torom”71. Pociąg zdawał się dlań reprezentować zjawisko, które Leo Marx - w odniesieniu do XIX-wiecznej prozy anglojęzycznej - określał mianem retoryki „technologicznej wzniosłości” (the rethotic of the technological sublime) ${ }^{72}$.

${ }^{68}$ Idem, Spojrzenie, [w:] idem, Niesamowita opowieść, s. 165.

${ }^{69}$ Reprezentatywny dla protagonistów obarczonych aberracją psychiczną jest bohater Fałszywego alarmu, poszukujący prawidłowości między tytułowym zdarzeniem a kolejowymi karambolami. Wykpiwany przez współpracowników doprowadza do katastrofy, aby udowodnić słuszność swej teorii. Równie odbiegający od społecznych stereotypów, związanych z wykonywaniem zawodu kolejarza, są inni bohaterowie opowieści z tomu Demon ruchu. Nadwrażliwość emocjonalna nie jest znamienna jedynie dla protagonistów nowel, które reprezentują nurt fantastyki grozy w pisarstwie Grabińskiego; również w utworach ukazujących zdarzenia pozostające w granicach prawdopodobieństwa (np. Sympatyk Proń, Porumbica, Wizyta) można odnaleźć podobne konstrukcje postaci.

70 Być może mamy w nowelistyce Grabińskiego do czynienia z aktualizacją zauważonej przez Annę Mostowską prawidłowości dotyczącej fascynacji tym, co w człowieku nieodgadnione: „Jest coś w człowieku, co nie może być odgadnione i co nas prowadzi do chęci nabycia Nadprzyrodzonych wiadomości. To wszystko, czego zrozumieć nie możemy, ma dla nas nieprzezwyciężony powab" (za: J. Gebethner, Poprzedniczka romantyzmu (Anna Mostowska), Kraków 1918, s. 73). Brak jednak świadectw, czy Grabiński znał studium Gebethnera, toteż zbieżność między postulatem Mostowskiej a praktyką twórczą autora Demona ruchu może być przypadkowa lub wynikać z szerszej prawidłowości, związanej z analogicznym co u Mostowskiej postrzeganiem elementu irracjonalnego $w$ kreacji bohatera literackiego.

${ }^{71}$ Nie oznacza to, że nie można w nowelistyce Grabińskiego odnaleźć opisów miejsc kojarzących się z konwencjonalna powieścia gotycką. Jako przykład przywołajmy ogród z Szalonej zagrody (z tomu Z wyjatków. W pomrokach wiary, s. 47): „Był bardzo stary i zapuszczony. Od lat wielu rozplenione chaszcze ujmowały go zewnątrz zwartym żywopłotem, strzegąc zazdrośnie tajemnicy wnętrza. Wśród chorobliwie wybujałych trawisk dziędzierzawy butwiały smukłe, przedwcześnie zmarniałe pnie młodych drzewin. Obaliły je nie wiatry, nie mające tu przystępu, lecz powolne, zjadliwe wysysanie im żywotnych soków przez starsze drzewa. Toteż wyschły jak szkielety z liśćmi o suchotniczych wypryskach". Innym opisem inspirowanym gotycką poetyką jest np. prezentacja zamku w Wampirze (z tomu Z wyjątków. W pomrokach wiary, s. 32-33) czy cmentarza w Opowieści o grabarzu („Maski” 1918, z. 31, s. 606). Jednakże zarówno wówczas, gdy Grabiński odwołuje się do zakorzenionego w społecznej wyobraźni imaginarium gotyckiego, jak i kiedy osadza fabułę w nowoczesnym krajobrazie technicznym, funkcjonalizuje przestrzeń akcji, czyniąc ją jednym z "mechanizmów strachu”.

72 L. Marx, The Machine in the Garden. Technology and the Pastoral Ideal in America, New York 2000, s. 195-207, 214, 230-231, 294-295. Wysoko nowelistykę Grabińskiego poświęconą kolei ocenia Edith Klapwijk, upatrująca w niej osobnego "gatunku fantastycznego" (le "genre fantastique") - zob. eadem, La Pologne: Grabiński, Schulz et Gombrowicz, [w:] Le Réalisme magique. Roman. Peinture. Cinéma, red. J. Weisgerber, Lausanne 1987, s. 202. 
Rewitalizacja kategorii estetycznej, konstytutywnej dla powieści gotyckiej, w nowelistyce Grabińskiego jest jednakże nie tylko przejawem przemian estetycznych, które musiały zajść w obliczu procesów związanych z industrializacją (kolej zaś to w międzywojniu wciąż symbol postępu). To również swoista deklaracja światopoglądowa pisarza, ukazującego na wzór autorów nurtu terror novel - mroczną stronę bytu. Artur Hutnikiewicz celnie zauważył:

Wszystkie najprostsze i najpowszechniejsze akcesoria środowiska, linie dróg żelaznych, wyprężone ku horyzontom, stacje i dworce pogrążone w sennej nudzie oczekiwania, nerwica podróżnych tłumów, jednostajny rytm nadbiegających i odchodzących pociągów, a jednocześnie ta nadbudowa fantastyczna, jaką konstruowała imaginacja poety na prozaicznym podścielisku powszednich faktów, błękitne mity ślepych torów, rozszalałe maszyny, pędzone wolą obłąkańców w bezkres przestrzeni, wszystko to urastało w opowieściach Grabińskiego do wymiaru symbolów wiecznego ruchu, $[\ldots]$ potężnego strumienia życiotwórczej energii, przenikającej wszechistnienie w niezmordowanym dążeniu ku ciągle nowej, tajemniczej przyszłości [TLSG, s. 80].

Odnajdywanie metafizycznego wymiaru postępu technologicznego zdaje się świadectwem recepcji postulatu Bolesława Prusa, który - referując pobyt w Warszawie słynnego włoskiego medium, Eusalpii Palladino - głosił konieczność stworzenia „nowej metafizyki”:

W tym wieku, który widoczniej, aniżeli wszystkie poprzednie dowiódł potęgi rozumu, który ducha tłumaczy chemią i fizyką, w tym wieku rozwija się jak nigdy spirytyzm. Fundamentem spirytyzmu nie są bynajmniej „media” $i$ „lewitacje”, lecz - potrzeba wiary w coś pozazmysłowego i pozażyciowego. Dlatego żadne rozumowania, żadne demaskowania, żadne szyderstwa - nie zabiją spirytyzmu. Dopiero gdy najnowsza fizyka na dnie swoich eterów i falowań odnajdzie ducha w naturze, a psychologia zwiąże go z uczuciem i pragnieniami człowieka, dopiero wówczas stoły umilkną, a media przestaną być przedmiotem pełnych podziwu obserwacyj ${ }^{73}$.

Beletrystyka Stefana Grabińskiego to przykład twórczości, która wciąż potrafi fascynować kolejne pokolenia amatorów „opowieści z dreszczykiem”74. Pośród spuścizny autora wy-

73 B. Prus, Eusalpia Palladino, „Kurier Codzienny” 1893, nr 353 (za: idem, Listy, oprac. K. Tokarzówna, Warszawa 1959, s. 199-200). Opinii Prusa można przeciwstawić słowa filozofa Jana Śniadeckiego, reprezentującego znamienne dla oświecenia zasady myślenia naukowego: „Prawdziwa filozofia zna granice ludzkiego pojęcia i za nie nie wykracza; zna słabość rozumu w rzeczach nawet jego dociekaniu zostawionych, a co krok ucząc się skromności, nie ośmiela się do przetrząsania tajemnic, od Twórcy sobie zabronionych" (idem, O filozofii, [w:] idem, Pisma filozoficzne, oprac. D. Petsch, Warszawa 1958, s. 177).

74 Powojenne odrodzenie fascynacji Grabińskim przyszło wraz z ekranizacją kilku jego opowiadań, które włączono do cyklu Opowieści niezwykłe - są to: Ślepy tor (1967, reż. Ryszard Ber) oraz Pożarowisko (1968, reż. Ryszard Ber) - oraz publikacją wybranych nowel w serii "Stanisław Lem Poleca” (1975) i najobszerniejszym dotychczas wyborem w trzytomowej edycji pod red. A. Hutnikiewicza (1980). W 1999 roku ukazała się nakładem Lampy i Iskry Bożej pierwsza pełna powojenna edycja Demona ruchu, a w opublikowanej 2009 roku antologii Tryptyk z dreszczykiem zamieszczono wybrane nowele z tomu Demon ruchu. Nowelistyka Grabińskiego popularna jest również na forach internetowych, zrzeszających miłośników fantastyki grozy. Wskazują oni na odmienność jego koncepcji ewokowania "mechanizmów strachu” od obowiązującego we współczesnej kulturze popularnej modelu "hollywoodzkiego", w którym subtelność sugerowania grozy zastąpiona została epatowaniem nią. Jeden z uczestników forum pisze: „U Grabińskiego znalazłem to, co najlepsze w literaturze straszącej. Nie epatowanie hektolitrami hemoglobiny, odrywanymi częściami ciała i upiornym wyglądem, ale wyrafinowane budowanie nastroju Grozy. Prawdziwa Groza nie wrzeszczy, nie bluzga, nie bucha i nie wybucha. Czai się cichutko za plecami, na bocznicach, w zaułkach, w opuszczonych domach... A kiedy beztrosko zapominamy o jej istnieniu, wypełza... Też po cichu... A gdy wreszcie przedrze się do naszych myśli, krzyczy- 
jątkowe miejsce zajmuje nowelistyka. Jest ona szczególnym świadectwem talentu pisarza, łączącego tradycję powieści grozy z nowoczesną rekwizytornią (zwłaszcza w tomie Demon ruchu) bądź wskrzeszającego konwencjonalną opowieść niesamowitą, reinterpretowaną przez pryzmat osiągnięć modnej już u progu międzywojnia psychoanalizy. $\mathrm{O}$ tym, że koncepcje Zygmunta Freuda i jego następców nie stanowiły w dwudziestoleciu międzywojennym jedynie modnej nowinki, lecz weszły na stałe do wyobraźni masowej, świadczy dramat Antoniego Cwojdzińskiego Freuda teoria snów $(1937)^{75}$. Nie należy jednak zapominać, że Cwojdziński należał do grona entuzjastów nauki, traktujących literaturę jako narzędzie do propagowania wiedzy scjentystycznej; był - prócz wspomnianej sztuki - autorem m.in. Teorii Einsteina (1934) oraz Temperamentów (1938), przybliżających teorię charakterologii Ernsta Kretschmera ${ }^{76}$.

Odmiennie niż Cwojdziński i inni propagatorzy nauki (m.in. Bruno Winawer), Grabiński nie traktował fabuł opowieści pretekstowo, jako punktu wyjścia do prezentacji popularyzowanych dzięki literaturze osiągnięć nauk społecznych i ścisłych. W jego twórczości zachodziła raczej odmienna relacja - to psychoanaliza i charakterologia Kretschmera traktowane jako punkt odniesienia i kulturowy kontekst pogłębiały wymowę opowieści.

my, uciekamy, bronimy się, atakujemy. A potem okazuje się, że widzieliśmy ją tylko my. No tak, bo to była Nasza Własna Groza. Wyhodowana na naszych lękach, a nie na hollywoodzkich scenariuszach klasy B" (Paetero, http://webcache.googleusercontent.com/search?q=cache:uil4Rmziu5kJ:www.slowobraz.net/2010/02/slepy-tor.html+film+\%C5\%9Blepy+tor\&cd=10\&hl=pl\&ct=clnk [dostęp: 24.04.2011]).

Dowodem nieustającego zainteresowania Grabińskim jest również reedycja noweli filmowej Ślepy tor na płycie DVD, dołączonej do periodyku "Sfera. Wydanie Specjalne” (2003); w numerze, prócz życiorysu Grabińskiego, zamieszczono trzy nowele: Ślepy tor, Wiecznego pasażera i W przedziale. Osobliwym świadectwem popularności twórczości tego autora jest przedsięwzięcie wydawnictwa "Carisma Entertainment Group", w ramach którego w 2009 roku ukazała się „Kolekcja Filmu Grozy”. Składały się na nią filmy utrzymane w poetyce fantastyki grozy wraz z dołączonymi nowelami Grabińskiego (m.in. Ślepym torem i Czerwonq Magdq). Nikłe zainteresowanie oferowanymi filmami sprawiło, że edycja ta rychło zniknęła z rynku.

${ }^{75}$ W komediowej formie Cwojdziński ukazuje - poprzez reductio ad absurdum - efekt konsekwentnie stosowanej psychoanalizy w pracy nad rolą aktora. Spotkanie pełnej temperamentu aktorki i autora sztuki, w której ma ona grać, to tyleż pretekst do przybliżenia Freudowskiej koncepcji, co budowania napięcia poprzez zderzenie dwu odmiennych charakterów. Współcześnie sztuka Cwojdzińskiego doczekała się adaptacji scenicznej, akcentującej głównie komediowy charakter perypetii bohaterów (1991, reż. Anna Minkiewicz).

76 Zob. L. Glinkowa, Teatr naukowy Cwojdzińskiego, „Poglądy” 1973, nr 16. Zjawisko wprowadzania do utworów fantastycznonaukowych wątków refleksji naukowej można uznać za wyraz szerszej tendencji poszukiwania przez literaturę schyłku XIX wieku nowych tematów, inspirowanych różnorodnymi modami. W ten sposób na fali fascynacji mediumizmem i teoriami Franza Mesmera powstały utwory, w których owe rewelacje sezonu zostały sprowadzone najczęściej do pretekstowej zabawy (Urocze oczy Zygmunta Sarneckiego, 1893) lub stanowiły oś fabularną (Hipnotyzm Jana Aleksandra Fredry, 1889; Stoliki magnetyczne Władysława Bogusławskiego, 1890). Jako punkt odniesienia dla utworów tych można przywołać anonimowy wstęp do Karczmy zaczarowanej, „Wiadomości Brukowe” 1821, nr 242, będący wyrazem czytelniczego zapotrzebowania na niesamowitość w literaturze popularnej doby romantyzmu (zob. A. Kowalczykowa, Romantyczne zaświaty, Wrocław 1974, s. 241).

Osobną kwestią jest, na ile można sygnalizowaną tu tendencję uznać za komplementarną wobec powstającego w tym samym czasie "romansu naukowego", który dał początek fantastyce naukowej tak, jak opowieści niesamowite wyewoluowały w horror. Równie odrębne pozostaje zagadnienie, czy - jak sugeruje Artur Hutnikiewicz - pisarze sięgający po zjawiska nadprzyrodzone czynili tak w odpowiedzi na zapotrzebowanie społeczne: „Epoka techniki, wielkich fabryk, kolei żelaznych, telegrafów, automobili i komfortu materialnego zatęskniła nagle za czarodziejską baśnią i zapragnęła wrażeń niezwykłych, których nie mogła jej dostarczyć kopiująca życie sztuka" (TLSG, s. 37). Zawężanie artystycznych poszukiwań do reakcji na industrializację przełomu XIX i XX w. zdaje się spłycać wydźwięk opisywanych przez Grabińskiego zjawisk. Twórczość fantastyczna to nie tylko (i nie przede wszystkim) „protest przeciwko jednostajności życia codziennego lub wyraz niepokoju metafizycznego" (TLSG, s. 121-122). Kwestię tę, należącą do zagadnień z kręgu psychologii odbioru, pozostawiamy nierozwiązaną. Być może mogłyby ją naświetlić badania interdyscyplinarne z pogranicza socjologii odbioru i psychologii. Odpowiedź na pytanie, dlaczego fantastyka cieszy się tak wielką popularnością, pozostaje jednakże na razie nierozstrzygnięte. 
Interesujące pod tym względem jest zestawienie poglądów niemieckiego badacza $\mathrm{z}$ ich artystyczną interpretacją Grabińskiego, np. Gebrowie (1922). O bohaterze noweli - pracowniku szpitala dla umysłowo chorych - czytamy:

Po kilku latach tak się oswoił z szaleńczą dziedziną, że stała mu się niejako drugą rzeczywistością i to znacznie głębszą i godniejszą uwagi, niż ta, w której obracali się ludzie poza jego zakładem. Dostrzegł w niej bowiem niejednokrotnie swoistą organizację opartą na żelaznej, nieublaganej logice. Co więcej, życie duchowe jego wychowanków wydawało mu się znacznie bogatsze, niż banalne historie przeciętniaków, odśpiewujących niezmiennie, aż do znudzenia monotonne litanie codzienności ${ }^{77}$.

Szaleństwo dość często w nowelach Grabińskiego jest sposobem na odkrycie „tajemnej strony bytu”, a choroba psychiczna bohatera umożliwia mu odczuwanie rzeczywistości głębiej niż w wypadku umysłów przeciętnych. Interesujące jest zwłaszcza zestawienie opinii Kretschmera, dotyczących szaleństwa, z wypowiedzią Grabińskiego, upatrującego w szaleństwie sposobu manifestacji geniuszu skazanego na ograniczone ułomnością tworzywa sposoby ujawnienia się: „Obłąkani - to często geniusze uczucia i myśli. Przepotężna namiętność lub ideał rozsadzają kruchą formę pozostawiając smutno-śmieszną karykaturę. Brak środków ekspresji i kruchość materiału do wypowiedzenia się - oto zwyczajna tragedia miliona bzików, oryginałów, wariatów, opętańców"78.

Zmiana relacji: artystyczna fantazja - popularyzacja nauki wynikała ze szczególnej koncepcji fantastyki w powieściopisarstwie Grabińskiego. Była ona dlań - przeciwnie niż dla popularyzatorów nauki - drogą do poszukiwania prawdy o bycie i człowieku, odsłanianej wybranym ${ }^{79}$.

Wykorzystując konwencjonalną scenerię i figury charakterystyczne dla literatury grozy, Grabiński odnowił ich znaczenia dzięki reinterpretacji. Sprawil, iż obiegowe motywy fantastyki grozy, które już u progu XX wieku były na tyle spetryfikowane, że pojawily się w powieści jarmarcznej, nabrały nowych znaczeń. Reprezentatywne dla sposobu korzystania z tradycji kulturowej są zwłaszcza aktualizacje dwu figur znamiennych dla fantastyki grozy: sobowtóra i wampira. Inwariantność ich opracowywania pozwala Grabińskiemu wydobywać tkwiące w nich sensy, odświeżając zarazem sposoby przywoływania ich przez twórców „opowieści z dreszczykiem” ${ }^{80}$.

77 S. Grabiński, Gebrowie, [w:] idem, Księga ognia, s. 86. Zob. opinię Kretschmera: „Popadlibyśmy w jaskrawy zatarg z olbrzymim materiałem faktów, gdybyśmy chcieli podtrzymywać zdanie wypowiadane przygodnie, że w geniuszu mamy uosobienie najwyższej siły i dzielności w biologicznym znaczeniu słowa. Nigdzie nie spotykamy takich rozbieżności w socjologicznej i biologicznej ocenie jak właśnie tutaj [...]. Gdy badamy [...] materiał biograficzny bez uprzedzeń i bez frazeologicznych upiększeń, rozwiewają się wszelkie wątpliwości co do tego, że między genialnością a dziedziną psychopatyczno-degeneratywną istnieją rzeczywiście poważne związki biologiczne" (idem, Ludzie genialni, tłum. P. Hulka-Laskowski, Warszawa 1934, s. 25-26).

${ }_{78}$ S. Grabiński, Z mojej pracowni. Opowieść o "Maszyniście Grocie”. Dzieje noweli - przyczynek do psychologii tworzenia, "Skamander" 1920, z. 2, s. 108

79 TLSG, s. 206. Interesującą relację między fantazją a realizmem w twórczości Grabińskiego kreśli Wojciech Tomasik: „Wszystko u Grabińskiego jest [...] zmyślone, ale niepokój ma być prawdziwy” (idem, op. cit., s. 140).

${ }^{80}$ W artystycznych powrotach Grabińskiego do określonych tematów można dostrzec metodę Poego. Franciszek Lyra pisał: „Poe rzadko poprzestawał na jednorazowym wykorzystaniu jakiegoś tematu, dlatego [...] jego nowelistyka jest bardziej spoista, niżby się to na pierwszy rzut oka wydawało" (idem, op. cit., s. 145). 
Narzucona konwencjonalnym figurom grozy psychoanalityczna interpretacja pozwala na pogłębienie sensów wykraczających poza „użytkowe” traktowanie tych postaci jako „narzędzi” wzbudzania strachu czytelnika. Sobowtór w nowelistyce Grabińskiego to - zgodnie z supozycją Andrew Webera - figura-klucz, umożliwiająca zrozumienie „inności” ${ }^{\text {. }}$. Wykładnia ta, wzbogacona odwołaniami do psychoanalizy i teorii podświadomości, kieruje czytelnika opowieści Grabińskiego w stronę refleksji psychologicznej i metafizycznej. Trop taki uprawomocnia wypowiedź Grabińskiego, który deklarował: „Jedynym motorem zdarzeń i wizji jest $[\ldots]$ dusza człowieka, jego tajemnicza, do dziś dnia niezbadana jaźń i jej cudowne, czasem groźne i niesamowite zdolności i sily" ${ }^{82}$. Podobne przeniesienie akcentów można dostrzec w nowelistyce Poego, którego zasługą było przede wszystkim - jak zauważa Benjamin F. Fisher - nadanie opowieściom grozy wymiaru psychologicznego ${ }^{83}$.

Protagonista i jego sobowtór stają w sytuacji spojrzenia w lustro; przyglądanie się własnemu odbiciu w obu wypadkach pozwala na ukazanie nie tylko fizyczności patrzącego, lecz również skłania do pytań o własną tożsamość ${ }^{84}$. Figury z imaginarium fantastyki grozy stają się w tym wypadku - podobnie jak w twórczości Poego - nośnikami szerszej, egzystencjalnej problematyki. Wybór tej postaci z kręgu figur charakterystycznych dla fantastki grozy jest nieprzypadkowy. To w sobowtórze bowiem, jak zauważa Maria Janion, koncentrują się najistotniejsze metafizyczne kwestie ludzkiego „ja”, a poczucie rozdwojenia można interpretować jako wyraz sprzecznej jedności pierwiastków najwyższych i najniższych, Dobra i Zła, świadomości i podświadomości, ciała i duszy ${ }^{85}$. Niekiedy figura sobowtóra aktualizowana jest w nowelistyce Grabińskiego dość osobliwie, jak w wypadku Cienia (1918). W utworze tym między tytułowym zjawiskiem a sobowtórem ukazano następującą paralelę:

Cień jest naiwną projekcją naszej jaźni na zmysłowym ekranie ziemi. Jest on zawsze zindywidualizowany; znać go tylko, gdy wyosobniony; stąd potrzeba mu światla, bez którego nie rozepnie tajemnych swych sieci. Jest przeciwstawianiem jednolitej ciemności, bo ta złą i niemoralną. Stąd dziwny lęk przed własnym cieniem. [...] Sobowtóry są w ogóle zjawiskiem niemiłym [...].

81 A. Weber, The Doppelgänger. Double Visions in German Literature, Oxford 1996, s. 10.

${ }^{82}$ S. Grabiński, O twórczości fantastycznej. Jej geneza i źródła. Wstęp do szkicu, „Lwowskie Wiadomości Muzyczne i Literackie" 1928, nr 10, s. 2.

${ }^{83}$ B. F. Fisher, Poe and the Gothic Tradition, [w:] The Cambridge Companion to Poe, ed. K. J. Hayes, Cambridge 2003, s. 78

${ }^{84}$ M. Głowiński, Narcyz i jego odbicia, „Twórczość" 1980, nr 10, s. 99-100.

85 Zob. M. Janion, Tajemnica sobowtóra, [w:] eadem, Romantyzm i jego media, oprac. M. Czermińska, Kraków 2001, s. 475. Zob. też opinię Janion z Gorączki i romantycznej, gdzie badaczka akcentuje konstytutywne dla romantyzmu przekonanie o dwoistości rzeczywistości (eadem, Goraczka romantyczna, Warszawa 1975, s. 169). Wyrazem wspominanej przez Janion "eksploatacji szaleństwa" jest m.in. popularny w romantyzmie motyw sobowtórowości bohatera, inspirowany antropozofią romantyków: „Jestestwo nasze w myśli się odbija. Odbijając się w myśli, dzieli się na dwoje. Myśl jest istotą naszej istoty, nosi w sobie nasz cień, nasze podobieństwo, nasz obraz. [...] Patrząc wewnątrz nas, widzimy samych siebie, wiemy samych siebie: dla samych siebie stajemy się przedmiotem widzenia i niejako rzeczą oddzielną. Póki nie przyjdziemy ku temu rozdwojeniu, póty nie mamy jestestwa" (M. Mochnacki, O literaturze polskiej w wieku dziewiętnastym, oprac. H. Życzyński, Kraków 1923, s. 25).

W psychoanalitycznej wykładni figury sobowtóra należy oczywiście pamiętać o granicach kanonu interpretacyjnego. W fantastyce grozy dominuje przede wszystkim nadprzyrodzoność, nie zaś symboliczna wykładnia zdarzeń. Toteż należy z ostrożnością podchodzić do reinterpretacji postaci Doppelgängera w duchu psychoanalizy (zob. D. A. Ringe, American Gothic. Imagination and Reason in Nineteenth-Century Fiction, Lexington 1982, s. 151; S. Studniarz, Tragiczna wizja. Rzecz o nowelistyce Poego, Toruń 2008, s. 62). Zob. uwagę Głowińskiego: „Jakiś element przeszłości, przejęty przez epokę współczesną, nie jest zjawiskiem samoistnym, jest określony przez system, jakiego elementem się staje" (idem, Tradycja literacka, s. 347). 
Cień jest poziomem wspólnym, na którym schadza się świat żyjący z tzw. martwym: wszystko, co istnieje, ma swój cień) ${ }^{86}$.

Niezależnie jednak, czy Grabiński reinterpretuje artystycznie nowatorsko przywoływaną figurę sobowtóra, czy też odwołuje się do jej postaci utrwalonej tradycją kulturową, można zauważyć wpływ na pisarską kreację romantycznej antropologii ${ }^{87}$.

„Pisarz współczesny może podejmować z przeszłości kulturalnej rzeczy rozmaite”8 zauważał Michał Głowiński, omawiając sposoby zakorzenienia się przez twórców w tradycji. Dla Stefana Grabińskiego ową „rzeczą” stało się - konstytutywne dla fantastyki grozy - podważenie oczywistości i jednowymiarowości świata, który można opisać za pomocą kategorii racjonalnych. Uniwersalny charakter jego opowieści zdaje się podkreślać inwariantyzm opracowywanych tematów i osadzanie ich w różnej scenerii: od południowoeuropejskiej, stylizowanej na charakterystyczną dla wczesnej powieści gotyckiej ${ }^{89}$ ( $N a$ wzgórzu róż, Wampir), poprzez imitującą realia współczesne czytelnikowi pisarza (Zez, Po stycznej, Ślepy tor, Wieczny pasażer, Spojrzenie), po futurystyczną (Dziwna stacja). Niekiedy - jak w wypadku trzech nowel - można mówić o różnym opracowaniu tego samego tematu artystycznego, jakim jest motyw klątwy. Grabiński, wykorzystując różne schematy fabularne i konstrukcyjne, stara się ukazać przekleństwo kolejno jako: wyraz przeświadczenia o obarczeniu „zlym okiem” (Puszczyk); ilustrację tezy psychologicznej o relacji między skutecznością przeklęcia a wiarą w nie (Klątwa); karę za złamanie ślubów (Podzwonne).

Ewa Piasecka widzi w przywołanych tu utworach ćwiczenia literackie, wskazując na inwariantny charakter opracowań wykorzystywanego motywu: „Młody autor wprawia się tu wyraźnie w rzemiośle $[\ldots]$, starając się do każdego z [... ] wariantów dostosować najodpowiedniejszy schemat fabularny oraz nagiąć temat i fabułę do wymogów konstrukcji nowelistycznej. Dzięki tym trzem utworom mamy możliwość obserwacji zmagań autora z materią artystyczną" ${ }^{\prime \prime 0}$. W podobnej perspektywie można rozpatrywać artystyczne powroty pisarza do wielokrotnie przywoływanych figur charakterystycznych dla konwencjonalnej fantastyki grozy.

Mimo obserwowanej w nowelistyce Grabińskiego modernizacji rozwiązań fabularnych, dostrzegalne jest zakorzenienie tej twórczości w tradycji fantastyki grozy, zwłaszcza inspirowanej XVIII-wiecznym gotycyzmem. Takie „powinowactwo z wyboru” uświadamia, że „mechanizmy strachu” (określenie Marka Wydmucha), pozwalające na budzenie emocji odbiorcy, się nie zmienily ${ }^{11}$. Odwołania Grabińskiego do rekwizytorni gotyckiej

86 S. Grabiński, Cień, s. 73-74.

87 Zob. Słownik literatury polskiej XIX wieku, s. 886, hasło: Sobowtór.

88 M. Głowiński, Tradycja literacka, s. 345.

89 Adam Rustowski zauważa, iż w powieści gotyckiej dość często akcja utworu rozgrywa się w Italii i Hiszpanii (idem, Angielska powieść gotycka doby wiktoriańskiej, Katowice 1977, s. 9). Wiąże się to, jego zdaniem, z wprowadzeniem figury "okrutnego mnicha-inkwizytora”, którego obecność motywowała przywołanie stereotypowych czytelniczych wyobrażeń na temat Świętej Inkwizycji i geopolitycznego zasięgu jej działania. Nie bez znaczenia dla takiej kreacji obrazu Świętej Inkwizycji było zapewne antykatolickie nastawienie prekursorów powieści gotyckiej: Ann Radcliffe i Horacego Walpole'a (zob. J. Krawczyk, Strawberry Hill Forever, „Mówią Wieki" 2005, nr 11, s. 38).

90 E. Piasecka, op. cit., s. 62.

91 Mechanizmy ewokowane przez twórców fantastyki grozy nie są wykorzystywane w sposób odizolowany - w ramach jednego utworu współistnieją różne metody budzenia emocji czytelnika, wzajemnie uzupełniające się (zob. A. Gemra, Uwieść strachem. Sterowanie emocjami odbiorcy we współczesnych tekstach grozy, [w:] Uwieść słowem, czyli retoryka stosowana, red. J. Z. Lichański, Warszawa 2003, s. 185-205).

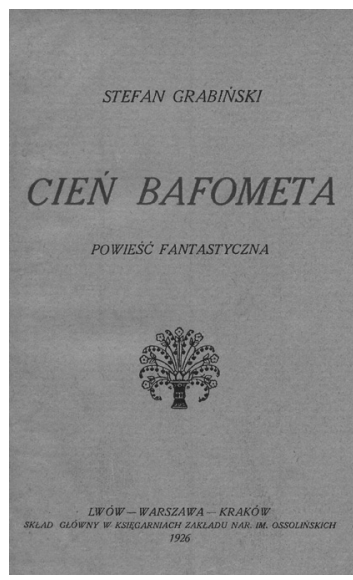

\section{S. Grabiński, Cień \\ Bafometa. Powieść}

fantastyczna, Zakład

Narodowy im. Ossolińskich, Lwów-Warszawa-Kraków 1926 
Karta pocztowa do Józefa Jedlicza z 26 VI 1931 r. Ze zbiorów Muzeum Literatury im. Adama Mickiewicza
OPIEKU J SIĘ DZIECKIEM - BĘDZIE MNIEJ WIĘZIEH I PRZESTĘPCÔW.

KARTKA POCZTOWA

NADAWCA:

M. P. i T: $(1-1931) 10.000 .000$

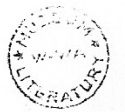

38

66

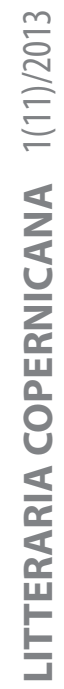

Cecigndry ì Krohrary Pamie.

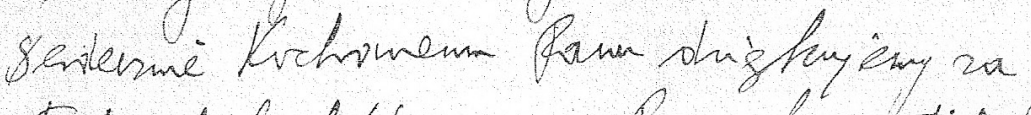

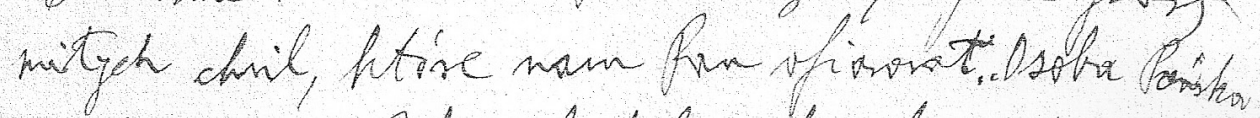

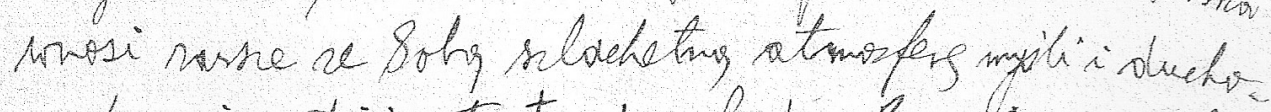

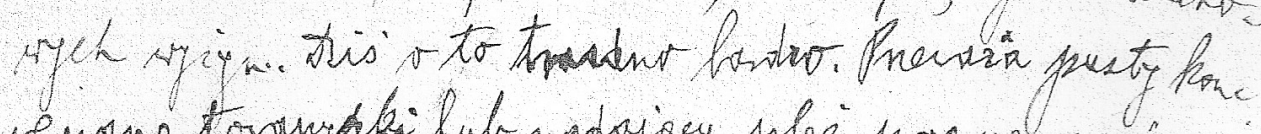

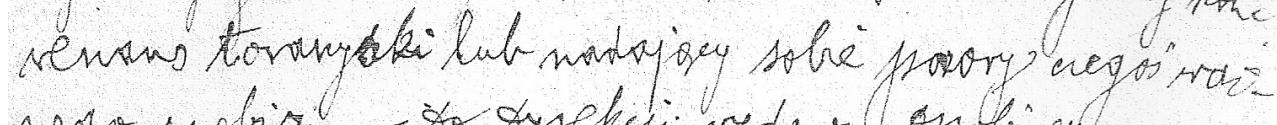

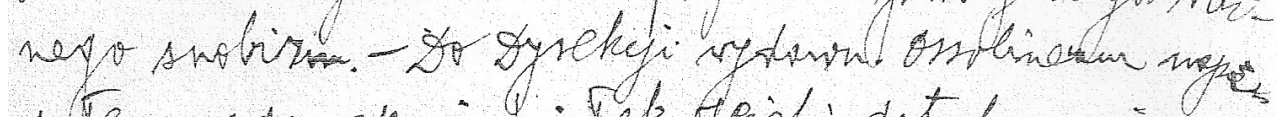

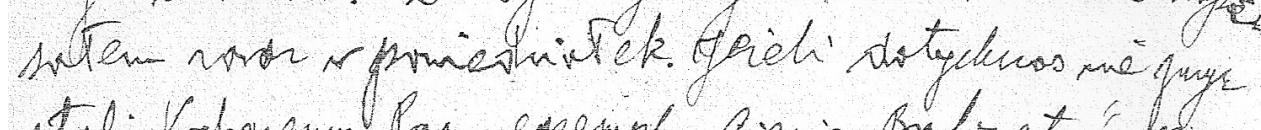

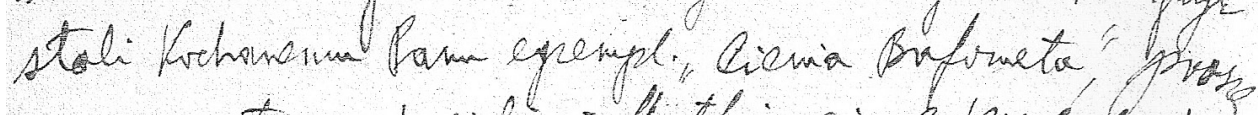

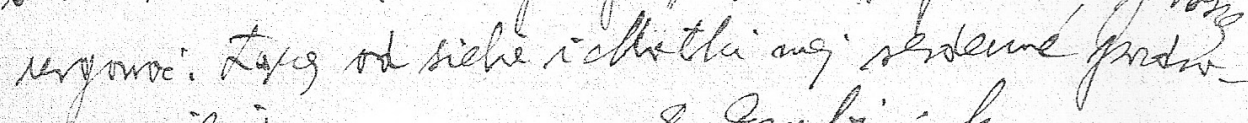
nievir

8. Orabinisho.

LC_11.indb 66

2013-06-21 08:33:51 
podlegają regułom szczególnej gry z czytelnikiem i nie mają jednoznacznego charakteru. Niekiedy (Fałszywy alarm, Pożarowisko) główne postaci to bezwolne marionetki, kierowane siłami, których nie są w stanie pojąć; kiedy indziej gotycka rekwizytornia, inspirowana romantyczną wyobraźnią, współtworzy paradygmat „postgotycyzmu”, w którym wyraża się głównie w warstwie słownej, dostosowując konstrukcję bohaterów do zmienionej wrażliwości i oczekiwań odbiorcy ${ }^{92}$.

Można zauważyć analogię między koncepcją fantastyki grozy Grabińskiego a dostrzeżonymi przez Arnolda Hausera prawidłowościami cechującymi pojęcie stylu. Zdaniem Hausera zjawisko struktury nie ulega zmianie nawet wówczas, gdy przetworzone zostały konkretne jej komponenty. Konfiguracja części składowych nie wpływa bowiem na sposób ich funkcjonowania w nadrzędnej całości ${ }^{93}$. Grabiński, nie rekonstruując przywoływanego wzorca powieści gotyckiej bądź Geistergeschichte w postaci historycznej, aktualizuje go jednocześnie tak, jak utrwalił się w świadomości czytelniczej. Z pierwotnych wzorców wydobywa to, co było dlań niezbędne do stworzenia własnego programu literackiego, w oparciu o doświadczenie przeszłości ${ }^{94}$. Uwewnętrznia przy tym - na wzór Poego - gotycyzm tak, że dawne symptomy cudowności „rozmywają się” w strumieniu świadomości protagonistów $^{95}$. Grozę bowiem, stanowiącą czynnik konstytutywny dla konstrukcji fabuły opowieści niesamowitej, mogą ewokować przecież nie tylko stare domostwa i posępne ruiny; skrywa się ona również w cieniach rozświetlonej elektrycznością nowoczesności ${ }^{96}$.

92 B. Zwolińska, op. cit., s. 76-79.

93 A. Hauser, The Philosophy of Art History, London 1959, s. 211.

${ }^{94}$ Kazimierz Wyka postępowanie takie, którego efektem jest włączenie zakorzenionych historycznie dyrektyw formotwórczych do własnej praktyki artystycznej, określa mianem „tradycji synkretycznej” (idem, Rzecz wyobraźni, Warszawa 1959, s. 180). Niekiedy (osobną kwestią jest, czy intencjonalnie) Grabiński tworzy parodie klisz młodopolskich, hiperbolizując elementy modernistycznej ikonosfery. Przykładem służy opis tytułowej istoty z Demona ruchu, mającej reklamować owe trasy kolejowe.

95 Na temat psychologizacji wzorca powieści gotyckiej w nowelistyce Poego zob. C. Griffith, Poe and the Gothic, [w:] Critical Essays on Edgar Allan Poe, ed. E. Carlson, Boston 1987, s. 127. Reprezentatywny dla tego procesu jest sposób opracowania motywu sobowtóra w Williamie Wilsonie Poego (zob. R. Przybylski, Dostojewski i„ „przeklęte problemy", Warszawa 1964, s. 89).

${ }_{96}$ Odnajdywanie przez Grabińskiego grozy w „krajobrazach nowoczesności” podkreśla Luis Rodrigues, prezentując sylwetkę pisarza w antologii opowiadań poświęconych fantastycznym obrazom miasta - zob. idem, Breaking Windows. A Fantastic Metropolis Sampler, Canton 2003, s. 190-191. Jako punkt odniesienia można wskazać dla tej metody sposób ewokowania grozy obecny w twórczości Charlesa Brockeda Browna (np. w powieściach Wieland, or The Transformation. An American Tale, 1798; Arthur Mervyn, 1799). Brown nie umieszczał fabuł w odległej przeszłości, lecz osadzał akcję we współczesnych realiach amerykańskich, koncentrując się na aberracjach psychicznych protagonistów, a jednocześnie zachowując aurę niepewności i niejednoznaczności wykładni tego, czego odbiorca jest świadkiem (E. Savoy, The Rise of American Gothic, [w:] The Cambridge Companion to Gothic Fiction, ed. J. Hogle, Cambridge 2002, s. 174-176, D. A. Ringe, op. cit., s. 49-53).

O przenikliwości Grabińskiego we wskazywaniu ikon postępu technologicznego jako źródła grozy świadczy fakt, iż tendencje do irracjonalizacji technologii można obserwować również obecnie; jej przykładem jest nurt folklorystyczny legend miejskich (urban legends), związanych m.in. z komputeryzacją życia, ujawniający demoniczne aspekty tego procesu. Rację miał przeto Jan Wyka: „Hegemonizm cywilizacji, odkrywczych wynalazków stara się wygonić z naszej optyki, z naszych przeżyć fantastykę i demonologię domorosłą [...]. Wątpię, czy miejsce tak zaborczo zajęte przez tzw. science fiction zdoła tamtą tematykę skazać na permanentne wygnanie" (idem, Literatura i upiory, s. 135). 